\title{
Biogeochemical controls on ammonium accumulation in the surface layer of the Southern Ocean
}

\author{
Shantelle Smith ${ }^{1}$, Katye E. Altieri ${ }^{1}$, Mhlangabezi Mdutyana ${ }^{1,2}$, David R. Walker ${ }^{3}$, Ruan G. Parrott ${ }^{1}$, Sedick Gallie ${ }^{3}$, \\ Kurt A. M. Spence ${ }^{1}$, Jessica M. Burger ${ }^{1}$, and Sarah E. Fawcett ${ }^{1,4}$ \\ ${ }^{1}$ Department of Oceanography, University of Cape Town, Private Bag X3, Rondebosch, Cape Town, South Africa \\ ${ }^{2}$ Southern Ocean Carbon and Climate Observatory (SOCCO), CSIR, Rosebank, Cape Town, South Africa \\ ${ }^{3}$ Department of Conservation and Marine Sciences, Cape Peninsula University of Technology, Cape Town, South Africa \\ ${ }^{4}$ Marine and Antarctic Research centre for Innovation and Sustainability (MARIS), \\ University of Cape Town, Cape Town, South Africa
}

Correspondence: Sarah Fawcett (sarah.fawcett@uct.ac.za)

Received: 9 June 2021 - Discussion started: 10 June 2021

Revised: 26 November 2021 - Accepted: 10 December 2021 - Published: 7 February 2022

\begin{abstract}
The production and removal of ammonium $\left(\mathrm{NH}_{4}^{+}\right)$ are essential upper-ocean nitrogen cycle pathways, yet in the Southern Ocean where $\mathrm{NH}_{4}^{+}$has been observed to accumulate in surface waters, its mixed-layer cycling remains poorly understood. For surface seawater samples collected between Cape Town and the Marginal Ice Zone in winter 2017, we found that $\mathrm{NH}_{4}^{+}$concentrations were 5-fold higher than is typical for summer and lower north than south of the Subantarctic Front $(0.01-0.26 \mu \mathrm{M}$ versus 0.19 $0.70 \mu \mathrm{M})$. Our observations confirm that $\mathrm{NH}_{4}^{+}$accumulates in the Southern Ocean's winter mixed layer, particularly in polar waters. $\mathrm{NH}_{4}^{+}$assimilation rates were highest near the Polar Front $\left(12.9 \pm 0.4 \mathrm{nM} \mathrm{d}^{-1}\right)$ and in the Subantarctic Zone $\left(10.0 \pm 1.5 \mathrm{nM} \mathrm{d}^{-1}\right)$, decreasing towards the Marginal Ice Zone $\left(3.0 \pm 0.8 \mathrm{nM} \mathrm{d}^{-1}\right)$ despite the high ambient $\mathrm{NH}_{4}^{+}$concentrations in these southernmost waters, likely due to the low temperatures and limited light availability. By contrast, rates of $\mathrm{NH}_{4}^{+}$oxidation were higher south than north of the Polar Front $\left(16.0 \pm 0.8\right.$ versus $\left.11.1 \pm 0.5 \mathrm{nM} \mathrm{d}^{-1}\right)$, perhaps due to the lower-light and higher-iron conditions characteristic of polar waters. $\mathrm{NH}_{4}^{+}$concentrations were also measured along five transects of the Southern Ocean (Subtropical Zone to Marginal Ice Zone) spanning the 2018/19 annual cycle. These measurements reveal that mixed-layer $\mathrm{NH}_{4}^{+}$accumulation south of the Subantarctic Front derives from sustained heterotrophic $\mathrm{NH}_{4}^{+}$production in late summer through winter that, in net, outpaces $\mathrm{NH}_{4}^{+}$removal by temperature-, light, and iron-limited microorganisms. Our observations thus im-
\end{abstract}

ply that the Southern Ocean becomes a biological source of $\mathrm{CO}_{2}$ to the atmosphere in autumn and winter not only because nitrate drawdown is weak but also because the ambient conditions favour net heterotrophy and $\mathrm{NH}_{4}^{+}$accumulation.

\section{Introduction}

The Southern Ocean impacts the Earth system through its role in global thermohaline circulation, which drives the exchange of heat and nutrients among ocean basins (Frölicher et al., 2015; Sarmiento et al., 2004). The Southern Ocean also plays an integral role in mediating climate, by transferring carbon to the deep ocean via its biological and solubility pumps (Sarmiento and Orr, 1991; Volk and Hoffert, 1985) and through the release of deep-ocean $\mathrm{CO}_{2}$ to the atmosphere during deep-water ventilation (i.e. $\mathrm{CO}_{2}$ leak; Broecker and Peng, 1992; Lauderdale et al., 2013; Sarmiento and Toggweiler, 1984). Upper Southern Ocean circulation is dominated by the eastward-flowing Antarctic Circumpolar Current (ACC) that consists of a series of broad circumpolar bands ("zones") separated by oceanic fronts. These fronts can drive water mass formation (Ito et al., 2010) and nutrient upwelling that supports elevated productivity (Sokolov and Rintoul, 2007).

Concentrations of the essential macronutrients, nitrate $\left(\mathrm{NO}_{3}^{-}\right)$and phosphate $\left(\mathrm{PO}_{4}^{3-}\right)$, are perennially high in Southern Ocean surface waters, in contrast to most of the global 
ocean. Assimilation of these nutrients, and thus primary productivity, is limited in the Southern Ocean by numerous overlapping factors, including temperature, light, micronutrient concentrations, and grazing pressure (e.g. Boyd et al., 2001; Martin et al., 1990; Reay et al., 2001; Smith and Lancelot, 2004). The strength of these limitations varies with sector (i.e. longitude), zone (i.e. latitude), and season, resulting in spatial and temporal variability in chlorophyll $a$, primary production, plankton community composition, and the nutrient uptake regime (Mdutyana et al., 2020; Mengesha et al., 1998; Shadwick et al., 2015; Thomalla et al., 2011). In addition to the seasonality of temperature and light, Southern Ocean ecosystems are influenced by seasonal changes in nutrient availability. In winter, deep mixing replenishes the nutrients required for phytoplankton growth but the low temperatures and light levels impede biological activity (Rintoul and Trull, 2001). Once the mixed layer shoals in spring and summer, phytoplankton consume the available nutrients until some form of limitation (usually iron; Nelson et al., 2001; Nicholson et al., 2019) sets in. This balance between wintertime nutrient recharge and summertime nutrient drawdown is central to the Southern Ocean's role in setting atmospheric $\mathrm{CO}_{2}$ (Sarmiento and Toggweiler, 1984).

The onset of iron limitation following the spring-earlysummer bloom in the Southern Ocean drives phytoplankton to an increased reliance on recycled ammonium $\left(\mathrm{NH}_{4}^{+}\right.$; Timmermans et al., 1998), the assimilation of which has a far lower iron requirement than that of $\mathrm{NO}_{3}^{-}$(Price et al., 1994). The extent to which phytoplankton rely on $\mathrm{NO}_{3}^{-}$versus $\mathrm{NH}_{4}^{+}$ as their primary $\mathrm{N}$ source has implications for Southern Ocean $\mathrm{CO}_{2}$ removal since phytoplankton growth fuelled by subsurface $\mathrm{NO}_{3}^{-}$("new production") must be balanced on an annual basis by the export of sinking organic matter ("export production"; Dugdale and Goering, 1967), which drives $\mathrm{CO}_{2}$ sequestration (i.e. the biological pump; Volk and Hoffert, 1985). By contrast, phytoplankton growth on $\mathrm{NH}_{4}^{+}$or other recycled $\mathrm{N}$ forms ("regenerated production") yields no net removal of $\mathrm{CO}_{2}$ to the deep ocean (Dugdale and Goering, 1967). Considerable research has focused on $\mathrm{NO}_{3}^{-}$cycling in the Southern Ocean mixed layer because of the importance of this nutrient for the biological pump (e.g. Francois et al., 1992; Johnson et al., 2017; Mdutyana et al., 2020; Primeau et al., 2013; Sarmiento and Toggweiler, 1984) and global ocean fertility (Fripiat et al., 2021; Sarmiento et al., 2004). By contrast, the cycling of regenerated $\mathrm{N}$ within the seasonally varying mixed layer - including the production of $\mathrm{NH}_{4}^{+}$and its removal by phytoplankton and nitrifiers - remains poorly understood.

$\mathrm{NH}_{4}^{+}$is produced in the euphotic zone as a by-product of heterotrophic metabolism (Herbert, 1999) and as a consequence of zooplankton grazing (Lehette et al., 2012; Steinberg and Saba, 2008), and it is removed by phytoplankton uptake (in euphotic waters) and nitrification (mainly in aphotic waters). Heterotrophic bacteria can also consume $\mathrm{NH}_{4}^{+}$(Kirchman, 1994) and have been hypothesised to do so at significant rates in the Southern Ocean mixed layer in winter (Cochlan, 2008; Mdutyana et al., 2020). The assimilation of $\mathrm{NH}_{4}^{+}$by phytoplankton requires relatively little energy (Dortch, 1990) such that $\mathrm{NH}_{4}^{+}$is usually consumed in the euphotic zone as rapidly as it is produced (Glibert, 1982; La Roche, 1983), resulting in very low surface $\mathrm{NH}_{4}^{+}$ concentrations in the open ocean $(<0.2 \mu \mathrm{M}$; Paulot et al., 2015). Additionally, $\mathrm{NH}_{4}^{+}$is often the preferred $\mathrm{N}$ source to small phytoplankton (Dortch, 1990), which typically dominate when iron and/or light are limiting (Deppeler and Davidson, 2017; Pearce et al., 2010; Tagliabue et al., 2014) since their higher cell surface-area-to-volume ratio renders them less vulnerable to diffusion limitation and/or light limitation (Finkel et al., 2004; Fujiki and Taguchi, 2002; Hudson and Morel, 1993; Mei et al., 2009).

In addition to the implications for size distribution, the dominant $\mathrm{N}$ source to phytoplankton is indicative of their potential for $\mathrm{CO}_{2}$ removal, as per the new production paradigm (Dugdale and Goering, 1967). The $\mathrm{N}$ isotopic composition $\left(\delta^{15} \mathrm{~N}\right.$, in $\%$, vs. $\mathrm{N}_{2}$ in air, equal to $\left.\left({ }^{15} \mathrm{~N} /{ }^{14} \mathrm{~N}_{\text {sample }} /{ }^{15} \mathrm{~N} /{ }^{14} \mathrm{~N}_{\text {air }}-1\right) \times 1000\right)$ of particulate organic N (PON, a proxy for phytoplankton biomass) can be used to infer the dominant $\mathrm{N}$ source to phytoplankton (Altabet, 1988; Fawcett et al., 2011, 2014; Lourey et al., 2003; Van Oostende et al., 2017) since the assimilation of subsurface $\mathrm{NO}_{3}^{-}$yields PON that is higher in $\delta^{15} \mathrm{~N}$ than that fuelled by recycled $\mathrm{NH}_{4}^{+}$uptake (Treibergs et al., 2014). As such, measurements of bulk $\delta^{15} \mathrm{~N}-\mathrm{PON}$ can be used to infer the net $\mathrm{N}$ uptake regime.

Nitrification, the oxidation of $\mathrm{NH}_{4}^{+}$to nitrite $\left(\mathrm{NO}_{2}^{-}\right)$and then $\mathrm{NO}_{3}^{-}$by chemoautotrophic bacteria and archaea, was historically considered unimportant in euphotic-zone waters due to the evidence for light inhibition of nitrifiers (Hooper and Terry, 1974; Horrigan and Springer, 1990; Olson, 1981) and the fact that they are outcompeted by phytoplankton for $\mathrm{NH}_{4}^{+}$(Smith et al., 2014; Ward, 1985, 2005; Zakem et al., 2018). However, this view has been challenged in numerous ocean regions (Yool et al., 2007), including the Southern Ocean (Smart et al., 2015; Cavagna et al., 2015; Fripiat et al., 2015; Mdutyana et al., 2020). Wintertime upper-ocean $\mathrm{NH}_{4}^{+}$ dynamics thus have implications for annual estimates of carbon export potential, insofar as $\mathrm{NO}_{3}^{-}$produced by nitrification in the winter mixed layer that is subsequently supplied to spring and summer phytoplankton communities constitutes a regenerated rather than a new $\mathrm{N}$ source on an annual basis (Mdutyana et al., 2020).

Surface concentrations of $\mathrm{NH}_{4}^{+}$are typically near zero in spring and early summer to mid-summer in the open Southern Ocean (Daly et al., 2001; Henley et al., 2020; Sambrotto and Mace, 2000; Savoye et al., 2004) due to assimilation by phytoplankton. In late summer, a peak in $\mathrm{NH}_{4}^{+}$concentration has been observed and attributed to enhanced bacterial and zooplankton activity following elevated phytoplankton growth (Becquevort et al., 2000; Dennett et al., 2001; Mengesha et al., 1998). The limited available observations suggest 
that wintertime surface $\mathrm{NH}_{4}^{+}$concentrations are high (often $>1 \mu \mathrm{M}$ ), particularly south of the Subantarctic Front (SAF) (Bianchi et al., 1997; Henley et al., 2020; Philibert et al., 2015; Mdutyana et al., 2020; Weir et al., 2020). It thus appears that $\mathrm{NH}_{4}^{+}$is not depleted following the late-summer peak in its concentration, which indicates enhanced $\mathrm{NH}_{4}^{+}$regeneration, coincident with (but in excess of) $\mathrm{NH}_{4}^{+}$assimilation in winter and/or prior to this in late summer and/or autumn. Under these conditions, the Southern Ocean mixed layer may become net heterotrophic and thus a biological source of $\mathrm{CO}_{2}$ to the atmosphere.

Here, we focus on $\mathrm{NH}_{4}^{+}$cycling in the Southern Ocean mixed layer, mainly in winter, which is a season assumed to be largely biologically dormant (Arrigo et al., 2008; Schaafsma et al., 2018) and for which $\mathrm{NH}_{4}^{+}$cycle data are scarce. We confirm that $\mathrm{NH}_{4}^{+}$accumulates throughout the winter mixed layer south of the SAF, and examine the potential drivers thereof. Using $\mathrm{NH}_{4}^{+}$concentration data collected over a full annual cycle, we propose that these drivers include a contribution from the residual late-summer $\mathrm{NH}_{4}^{+}$pool, sustained $\mathrm{NH}_{4}^{+}$production in the autumn and winter, and limited wintertime $\mathrm{NH}_{4}^{+}$uptake and oxidation that nonetheless exceed the rate of in situ $\mathrm{NH}_{4}^{+}$production. Finally, from our temporally resolved $\mathrm{NH}_{4}^{+}$concentration data, we propose for the first time - a measurement-based seasonal cycle for the mixed-layer $\mathrm{NH}_{4}^{+}$pool south of the SAF.

\section{Methods}

\subsection{Cruise tracks and sample collection}

Samples were collected for a series of analyses on the southward (S) and northward (N) legs of a winter cruise between Cape Town, South Africa, and the Marginal Ice Zone (MIZ) on board the R/V SA Agulhas II (VOY025; 28 June to 13 July 2017) (Fig. 1). Samples were also collected for $\mathrm{NH}_{4}^{+}$concentration analysis on three cruises on board the R/V SA Agulhas II during 2018-2019: early- and late-summer samples were collected during the SANAE 58 relief voyage (6 December 2018 to 15 March 2019; VOY035); winter samples were collected during the SCALE 2019 (http://scale.org.za/, last access: 17 January 2022) winter cruise to the MIZ (18 July to 12 August 2019; VOY039); and spring samples were collected during the SCALE 2019 spring cruise to the MIZ (12 October to 20 November 2019; VOY040) (Fig. S1).

Leg S of VOY025 in winter 2017 crossed the Atlantic sector and, due to logistical constraints, involved only surface underway collections, while leg $\mathrm{N}$ bordered the Atlantic and Indian sectors $\left(30^{\circ} \mathrm{E}\right.$, WOCE IO6 line) and included eight conductivity-temperature-depth (CTD) hydrocast stations. Frontal positions were determined using the ship's hull-mounted thermosalinograph, supported by temperature, salinity, and oxygen concentration data from CTD measurements made during leg $\mathrm{N}$. The salinity and oxygen sensors

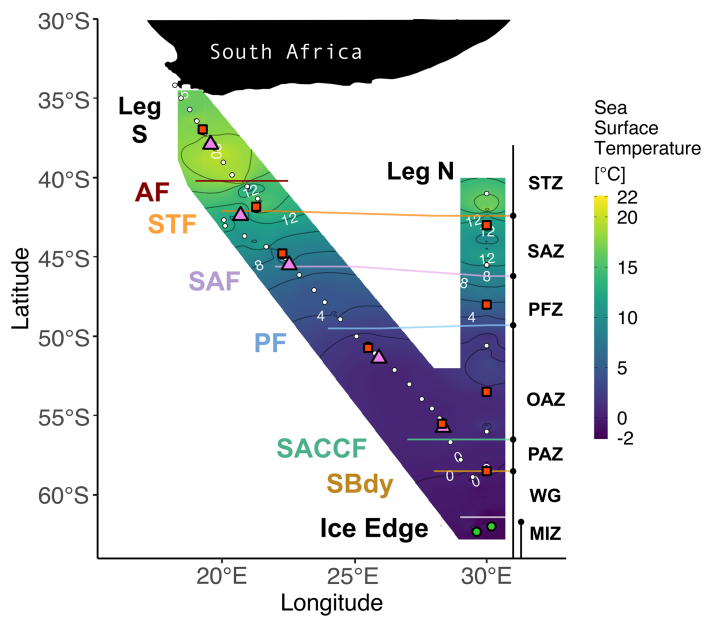

Figure 1. Winter 2017 cruise track overlaid on sea surface temperature (SST) measured by the hull-mounted thermosalinograph. The underway (leg S) and CTD (leg N) stations are indicated by white circles. Stations at which net primary production (NPP), nitrogen uptake, and ammonium oxidation experiments were conducted are denoted by red squares. The pink triangles indicate stations where only NPP experiments were conducted, and the green circles show stations where only ammonium oxidation was measured. Solid lines indicate the positions of the fronts, identified from measurements of temperature and salinity. Abbreviations for fronts: AF - Agulhas Front $\left(\sim 40.2^{\circ} \mathrm{S}\right)$; STF - Subtropical Front $\left(\sim 42.1^{\circ} \mathrm{S}\right)$; SAF - Subantarctic Front $\left(\sim 45.6^{\circ} \mathrm{S}\right)$; PF - Polar Front $\left(\sim 49.5^{\circ} \mathrm{S}\right)$; SACCF - Southern Antarctic Circumpolar Current Front $\left(\sim 56.5^{\circ} \mathrm{S}\right)$; SBDY - Southern Boundary $\left(\sim 58.5^{\circ} \mathrm{S}\right)$. Abbreviations for zones: STZ - Subtropical Zone; SAZ - Subantarctic Zone; PFZ - Polar Frontal Zone; OAZ - Open Antarctic Zone; PAZ - Polar Antarctic Zone; WG - Weddell Gyre; MIZ - Marginal Ice Zone. Together, the OAZ and PAZ constitute the Antarctic Zone (AZ). See Sect. S1 for detailed definitions of the fronts and zones. Figure produced using the package ggplot2 (Wickham, 2016).

were calibrated against seawater samples that were analysed for salinity using a Portasal $8410 \mathrm{~A}$ salinometer and for dissolved oxygen by Winkler titration (Strickland and Parsons, 1972). Frontal positions were determined from sharp gradients in potential temperature, salinity, potential density, and oxygen concentrations (Belkin and Gordon, 1996; Lutjeharms and Valentine, 1984; Orsi et al., 1995). For leg N, the mixed-layer depth (MLD) was determined for each Niskin (up)cast as the depth between 10 and $400 \mathrm{~m}$ at which the Brunt-Väisälä frequency squared, $N^{2}$, reached a maximum (Carvalho et al., 2017).

During leg S, samples were collected every $4 \mathrm{~h}$ from the ship's underway system $(\sim 7 \mathrm{~m}$ intake; "underway stations"), while samples on leg $\mathrm{N}$ were collected from surface Niskin bottles ( $\sim 10 \mathrm{~m}$, approximately $55 \%$ light depth) mounted on the CTD rosette ("CTD stations"). $\mathrm{NH}_{4}^{+}$samples were also taken at 13 depths over the upper $500 \mathrm{~m}$ at the CTD stations. During the 2018-2019 cruises, $\mathrm{NH}_{4}^{+}$sam- 
ples were collected every $2 \mathrm{~h}$ from the ship's underway system. At all stations, $40 \mathrm{~mL}$ of unfiltered seawater was collected for the analysis of $\mathrm{NH}_{4}^{+}$concentrations in duplicate $50 \mathrm{~mL}$ high-density polyethylene (HDPE) bottles that had been stored ("aged") with an orthophthaldialdehyde (OPA) working reagent. Unfiltered seawater was collected in duplicate $50 \mathrm{~mL}$ polypropylene centrifuge tubes for the analysis of $\mathrm{NO}_{3}^{-}, \mathrm{NO}_{2}^{-}$, and $\mathrm{PO}_{4}^{3-}$ and in a single tube for urea. Immediately following collection, $\mathrm{NH}_{4}^{+}$and nutrient samples were frozen at $-20^{\circ} \mathrm{C}$.

Duplicate size-fractionated chlorophyll $a$ samples were collected by filtering seawater $(500 \mathrm{~mL})$ through $25 \mathrm{~mm}$ diameter glass fibre filters $(0.3$ and $2.7 \mu \mathrm{m}$; Sterlitech GF-75 and Grade D, respectively). Acetone (90\%) was added to foil-wrapped borosilicate tubes containing the filters and incubated at $-20^{\circ} \mathrm{C}$ for $24 \mathrm{~h}$. Duplicate seawater samples (4 L) were also gently vacuum filtered through combusted $47 \mathrm{~mm}$ diameter, $0.3 \mu \mathrm{m}$ GF-75 and $2.7 \mu \mathrm{M}$ Grade-D filters for POC and PON concentrations and $\delta^{15} \mathrm{~N}-\mathrm{PON}$. Filters were stored in combusted foil envelopes at $-80^{\circ} \mathrm{C}$.

For microscopy, unfiltered seawater samples $(250 \mathrm{~mL})$ were collected during leg $\mathrm{S}$ in amber glass bottles and immediately fixed by the addition of $2.5 \mathrm{~mL}$ of Lugol's iodine solution ( $2 \%$ final concentration) and then stored at low room temperature in the dark until analysis. For flow cytometry, seawater samples were collected in triplicate $2 \mathrm{~mL}$ microcentrifuge tubes, fixed with glutaraldehyde ( $1 \%$ final concentration), and stored at $-80^{\circ} \mathrm{C}$ until analysis (Marie et al., 2005).

Ten incubation experiments were conducted during leg $\mathrm{S}$ to measure net primary production (NPP). In addition, four NPP experiments were conducted during leg $\mathrm{N}$ using seawater collected from Niskin bottles fired at $\sim 10 \mathrm{~m}$. In all cases, pre-screened ( $200 \mu \mathrm{m}$ mesh, to remove large grazers) seawater was collected in three $2 \mathrm{~L}$ polycarbonate bottles to which $\mathrm{NaH}^{13} \mathrm{CO}_{3}$ was added at $\sim 5 \%$ of the estimated ambient dissolved inorganic carbon (DIC) concentration. Enrichment of ${ }^{13} \mathrm{C}$ was re-calculated post-cruise using measured DIC concentrations, and these enrichments were used in all NPP rate calculations. Bottles were incubated for 5 to $6.5 \mathrm{~h}$ in custom-built deck-board incubators shaded with neutraldensity screens to mimic the $55 \%$ light level and supplied with running surface seawater. Following incubation, each sample was divided ( $1 \mathrm{~L}$ per size fraction) and gently vacuum filtered through combusted 0.3 and $2.7 \mu \mathrm{m}$ glass fibre filters that were stored in combusted foil at $-80^{\circ} \mathrm{C}$ until analysis.

$\mathrm{N}$ uptake (as $\mathrm{NO}_{3}^{-}, \mathrm{NH}_{4}^{+}$, and urea) and $\mathrm{NH}_{4}^{+}$oxidation experiments were conducted at five stations during leg $\mathrm{S}$, with $\mathrm{NH}_{4}^{+}$oxidation measured at two additional stations at the ice edge (Fig. 1). On leg N, experiments were also conducted using seawater collected from $\sim 10 \mathrm{~m}$ at the same four CTD stations as in the NPP experiments. Duplicate $1 \mathrm{~L}$ polycarbonate bottles were amended with ${ }^{15} \mathrm{~N}$-labelled $\mathrm{NO}_{3}^{-}$, $\mathrm{NH}_{4}^{+}$, or urea at $\sim 10 \%$ of the ambient $\mathrm{N}$ concentration, estimated based on past wintertime measurements (Mdutyana et al., 2020) and, in the case of $\mathrm{NH}_{4}^{+}$, coincident shipboard analyses. Enrichment of ${ }^{15} \mathrm{~N}$ was re-calculated post-cruise using the measured nutrient concentrations, and these enrichments were used in all rate calculations. Incubations and filtration were carried out as for NPP, although $500 \mathrm{~mL}$ was used per size fraction. For $\mathrm{NH}_{4}^{+}$oxidation, duplicate $250 \mathrm{~mL}$ black HDPE bottles were amended with $0.1 \mu \mathrm{M}^{15} \mathrm{NH}_{4}^{+}$and $0.1 \mu \mathrm{M}^{14} \mathrm{NO}_{2}^{-}$(the latter as a "trap" for the ${ }^{15} \mathrm{NO}_{2}^{-}$produced by $\mathrm{NH}_{4}^{+}$oxidation; Ward, 2011). $\mathrm{NH}_{4}^{+}$oxidation bottles were incubated for $24 \mathrm{~h}$ under the same temperature conditions as the N uptake and NPP experiments. Subsamples $(50 \mathrm{~mL})$ were collected from each bottle immediately following tracer addition $\left(T_{0}\right)$ and at the end of the experiments $\left(T_{\mathrm{f}}\right)$ and frozen at $-20^{\circ} \mathrm{C}$ until analysis.

\subsection{Sample processing}

\subsubsection{Ammonium concentrations}

On all cruises, $\mathrm{NH}_{4}^{+}$concentrations were measured shipboard using the fluorometric method of Holmes et al. (1999) and a Turner Designs Trilogy 7500-000 fluorometer equipped with a UV module. The detection limit, calculated as twice the pooled standard deviation (SD) of all standards, was $0.06 \mu \mathrm{M}$. To prevent possible influx and/or efflux of ammonia $\left(\mathrm{NH}_{3}\right)$ due to the temperature difference between surface waters and the shipboard laboratory, samples were frozen immediately upon collection, for a maximum of $24 \mathrm{~h}$. OPA working reagent was added to the frozen samples prior to defrosting them for analysis. Samples were slowly warmed to room temperature in a water bath after OPA addition and incubated in the dark for $4 \mathrm{~h}$ once defrosted, and then each replicate was measured in triplicate. Standards and blanks were made daily using Type-1 Milli-Q water. Precision was $\pm 0.03 \mu \mathrm{M}$ for replicate samples and standards.

During VOY040 (spring 2019), we investigated the possibility that the ship's underway system alters the seawater $\mathrm{NH}_{4}^{+}$concentrations (e.g. due to contamination or cell breakage). We collected surface samples from the underway and Niskin bottles concurrently and measured an average $\mathrm{NH}_{4}^{+}$concentration difference of $0.07 \pm 0.15 \mu \mathrm{M}(n=17)$, with no noticeable trend of one method consistently yielding higher/lower concentrations. We thus have no reason to doubt $\mathrm{NH}_{4}^{+}$concentrations measured for seawater samples collected from the ship's underway system.

\subsubsection{Macronutrient concentrations}

Following the winter 2017 cruise, duplicate seawater samples were analysed manually for $\mathrm{NO}_{2}^{-}$and $\mathrm{PO}_{4}^{3-}$ (Bendschneider and Robinson, 1952; Murphy and Riley, 1962) using a Thermo Scientific Genesys 30 Visible spectrophotometer. The precision and detection limit were $\pm 0.05 \mu \mathrm{M}$ and $0.05 \mu \mathrm{M}$ for $\mathrm{NO}_{2}^{-}$and $\pm 0.06 \mu \mathrm{M}$ and $0.05 \mu \mathrm{M}$ for $\mathrm{PO}_{4}^{3-}$. The concentrations of $\mathrm{NO}_{3}^{-}+\mathrm{NO}_{2}^{-}$and $\mathrm{Si}(\mathrm{OH})_{4}$ were measured using a Lachat QuikChem 8500 Series 2 flow in- 
jection autoanalyser. Aliquots of a certified reference material (JAMSTEC) were measured during each run to ensure measurement accuracy ( $\mathrm{SD} \leq 2 \%$ ). The precision of the $\mathrm{NO}_{3}^{-}+\mathrm{NO}_{2}^{-}$and $\mathrm{Si}(\mathrm{OH})_{4}$ measurements was $\pm 0.4 \mu \mathrm{M}$ and $\pm 0.2 \mu \mathrm{M}$, respectively, and the detection limit was 0.1 and $0.2 \mu \mathrm{M}$. $\mathrm{NO}_{3}^{-}$concentrations were calculated by subtraction (i.e. $\mathrm{NO}_{3}^{-}+\mathrm{NO}_{2}^{-}-\mathrm{NO}_{2}^{-}$), with error propagated according to standard statistical practices. Urea $\mathrm{N}$ (hereafter, urea) concentrations were determined via the room-temperature, single-reagent colorimetric method (Revilla et al., 2005) using a Thermo Scientific Genesys 30 Visible spectrophotometer; precision was $\pm 0.04 \mu \mathrm{M}$, and the detection limit was $0.04 \mu \mathrm{M}$.

\subsubsection{Chlorophyll $a$ concentrations}

Chlorophyll $a$ concentrations ([chl $a$ ) were determined shipboard using the nonacidified fluorometric method (Welschmeyer, 1994). The Turner Designs Trilogy fluorometer was calibrated with an analytical standard (Anacystis nidulans, Sigma-Aldrich ${ }^{\circledR}$ ) prior to and following the cruise. The [chl $a$ ] of the $0.3-2.7 \mu \mathrm{m}$ size class (hereafter, "pico" size class) was calculated by subtracting the measured [chl $a$ ] of the $>2.7 \mu \mathrm{m}$ size class (hereafter, "nano+" size class) from the $>0.3 \mu \mathrm{m}$ size class (hereafter, "bulk"). Given previous work showing that the winter Southern Ocean phytoplankton community is composed primarily of small cells (i.e. typically $<15 \mu \mathrm{m}$; e.g. Hewes et al., 1985, 1990; Weber and El-Sayed, 1987), we did not separate micro- from nanophytoplankton.

\subsubsection{Bulk POC, PON, and $\delta^{15} \mathrm{~N}-\mathrm{PON}$}

The NPP and N uptake filters were fumed with hydrochloric acid in a desiccator for $24 \mathrm{~h}$ to remove inorganic carbon and then dried for $24 \mathrm{~h}$ at $40^{\circ} \mathrm{C}$ and packaged into tin cups. Filters for $\delta^{15} \mathrm{~N}-\mathrm{PON}$ were dried in the same way but not acidified. Samples were analysed using a Delta V Plus isotope ratio mass spectrometer (IRMS) coupled to a Flash 1112 Series Elemental Analyzer, with a detection limit of $0.17 \mu \mathrm{mol} \mathrm{C}$ and $0.07 \mu \mathrm{mol} \mathrm{N}$ and precision of \pm 0.005 at. \% for $\mathrm{C}$ and $\mathrm{N}$. Unused pre-combusted filters (blanks) were included in each batch run. POC and PON content was determined from daily standard curves of the IRMS area versus known $\mathrm{C}$ and $\mathrm{N}$ masses. For the isotope ratios, sample measurements were referenced to internal laboratory standards calibrated against IAEA reference materials that were measured after every five to seven samples.

\subsubsection{Size-fractionated rates of NPP and N uptake}

Carbon and $\mathrm{N}$ uptake rates (NPP, $\rho \mathrm{NH}_{4}^{+}, \rho \mathrm{NO}_{3}^{-}, \rho$ Urea) were calculated according to Dugdale and Wilkerson (1986) as

$$
\begin{aligned}
& \rho M=\frac{[\mathrm{PM}] \times\left(\text { at. } \%_{\text {meas }}-\text { at. } \%_{\mathrm{amb}}\right)}{T \times\left(\text { at. } \%_{\text {init }}-\text { at. } \%_{\mathrm{amb}}\right)}, \text { where } \\
& \text { at. } \%_{\text {init }}=\frac{\left([M] \times \text { at. } \%_{\mathrm{amb}}\right)+\left(\left[M_{\text {tracer }}\right] \times \text { at. } \%_{\text {tracer }}\right)}{[M]+\left[M_{\text {tracer }}\right]} .
\end{aligned}
$$

Here, $M$ is the species of interest $\left(\mathrm{C}, \mathrm{NH}_{4}^{+}, \mathrm{NO}_{3}^{-}\right.$, or urea); $\rho \mathbf{M}$ is the uptake rate of that species $\left(\mathrm{nM} \mathrm{h}^{-1}\right.$, i.e. $\mathrm{nmol} \mathrm{C}$ or $\mathrm{NL}^{-1} \mathrm{~h}^{-1}$ ); [PM] is the concentration of POC or PON $(\mu \mathrm{M})$ on the filters; $[M]$ is the ambient concentration of DIC, $\mathrm{NH}_{4}^{+}, \mathrm{NO}_{3}^{-}$, or urea at the time of sample collection; $\left[M_{\text {tracer }}\right]$ is the concentration of $\mathrm{NaH}^{13} \mathrm{CO}_{3},{ }^{15} \mathrm{NH}_{4}^{+},{ }^{15} \mathrm{NO}_{3}^{-}$, or ${ }^{15} \mathrm{~N}$ urea added to the incubation bottles; and $T$ is the incubation period (hours). DIC concentrations were measured shipboard using a VINDTA 3C instrument and ranged from 2017 to $2130 \mu \mathrm{M}$ (Bakker et al., 2016). The PM and $\rho \mathrm{M}$ of the picoplankton size class were calculated by subtracting the nanoplankton from the bulk measurements. Daily rates were computed by multiplying the hourly rates by the number of daylight hours, the latter calculated using the sampling latitude and day of the year (Forsythe et al., 1995).

The $f$ ratio (Eppley and Peterson, 1979), used to estimate the fraction of NPP potentially available for export, was calculated as

$f$ ratio $=\frac{\rho \mathrm{NO}_{3}^{-}}{\rho N_{\text {tot }}}$,

where $\rho \mathrm{N}_{\text {tot }}=\rho \mathrm{NH}_{4}^{+}+\rho \mathrm{NO}_{3}^{-}+\rho$ Urea. Urea uptake was not measured at underway stations 50.7 and $55.5^{\circ} \mathrm{S}$ (both in the Antarctic Zone); here, the $f$ ratio was calculated omitting $\rho$ Urea. For the two Antarctic Zone stations at which urea uptake was measured, including $\rho$ Urea decreased the $f$ ratio by $8 \%-25 \%$ compared to that calculated using only $\rho \mathrm{NO}_{3}^{-}$ and $\rho \mathrm{NH}_{4}^{+}$.

\subsubsection{Ammonia oxidation rates}

The azide method (McIlvin and Altabet, 2005) was used to convert $\mathrm{NO}_{2}^{-}$produced by $\mathrm{NH}_{4}^{+}$oxidation to $\mathrm{N}_{2} \mathrm{O}$ gas that was measured using a Delta V Plus IRMS with a custombuilt purge-and-trap front end (McIlvin and Casciotti, 2011). This configuration yields a detection limit of $0.2 \mathrm{nmolN}$ with a $\delta^{15} \mathrm{~N}$ precision of $\pm 0.1 \%$. The $\delta^{15} \mathrm{~N}_{\text {of }} \mathrm{NO}_{2}^{-}$was derived from ${ }^{45} \mathrm{~N}_{2} \mathrm{O} /{ }^{44} \mathrm{~N}_{2} \mathrm{O}$, and the rate of $\mathrm{NH}_{4}^{+}$oxidation $\left(\mathrm{NH}_{4}^{+}\right.$ox $\left.; \mathrm{nMd}^{-1}\right)$ was calculated following Peng et al. (2015) as

$\mathrm{NH}_{4 \text { ox }}^{+}=\frac{\Delta\left[{ }^{15} \mathrm{NO}_{2}^{-}\right]}{f_{\mathrm{NH}_{4}^{+}}^{15} \times T}$.

Here, $\Delta\left[{ }^{15} \mathrm{NO}_{2}^{-}\right]$is the change in the concentration of ${ }^{15} \mathrm{NO}_{2}^{-}$ $(\mathrm{nM})$ between the start and end of the incubation, calculated as the difference in the measured $\delta^{15} \mathrm{~N}$ of $\mathrm{NO}_{2}^{-}$between the 
$T_{\mathrm{f}}$ and $T_{0}$ samples; $f_{\mathrm{NH}_{4}^{+}}^{15}$ is the fraction of the $\mathrm{NH}_{4}^{+}$substrate labelled with ${ }^{15} \mathrm{~N}$ at the start of the incubation; and $T$ is the incubation length (days). All ${ }^{15} \mathrm{NO}_{2}^{-}$produced during the incubations was assumed to derive from ${ }^{15} \mathrm{NH}_{4}^{+}$oxidation. The detection limit ranged from 0.02 to $0.11 \mathrm{nM} \mathrm{d}^{-1}$, calculated according to Santoro et al. (2013).

We note that isotope dilution (i.e. the dilution of ${ }^{15} \mathrm{NH}_{4}^{+}$by co-occurring ${ }^{14} \mathrm{NH}_{4}^{+}$regeneration) during the $\mathrm{NH}_{4}^{+}$uptake and oxidation experiments could potentially lead to an underestimation of the rates (Glibert, 1982; Mdutyana, 2021). For the $\mathrm{NH}_{4}^{+}$uptake experiments, their short duration (3 to $7.5 \mathrm{~h}$ ) would have rendered the effect of regeneration minor (Mdutyana et al., 2020). Moreover, the ${ }^{15} \mathrm{NH}_{4}^{+}$additions were high $(100 \mathrm{nM})$ relative to both the ambient $\mathrm{NH}_{4}^{+}$concentrations north of the SAF and the $K_{\mathrm{m}}$ values derived for $\mathrm{NH}_{4}^{+}$uptake and oxidation in the winter Southern Ocean (150-405 and 28-137 nM, respectively; Mdutyana, 2021), making a significant dilution effect unlikely (Lipschultz, 2008). Finally, at the stations south of the SAF, the ambient $\mathrm{NH}_{4}^{+}$concentrations were so high that even if the regeneration of ${ }^{14} \mathrm{NH}_{4}^{+}$occurred at an elevated rate (e.g. $50 \mathrm{nM} \mathrm{d}^{-1}$, as has been measured in the late-summer Southern Ocean when remineralisation is expected to be high; Goeyens et al., 1991), the ${ }^{15} \mathrm{~N} /{ }^{14} \mathrm{~N}$ of the $\mathrm{NH}_{4}^{+}$pool would decrease by $<1 \%-2 \%$. We thus consider the potential effect of isotope dilution to be minor.

A further consideration is possible stimulation of the $\mathrm{NH}_{4}^{+}$ uptake and oxidation rates by ${ }^{15} \mathrm{NH}_{4}^{+}$addition (Lipschultz, 2008). Given the $K_{\mathrm{m}}$ values listed above and the high ambient $\mathrm{NH}_{4}^{+}$concentrations measured in the $\mathrm{PFZ}$ and $\mathrm{AZ}$, a stimulation effect could be significant only at the stations north of the SAF where the $\mathrm{NH}_{4}^{+}$concentrations were 10$100 \mathrm{nM}$ and, even then, to a lesser extent for $\mathrm{NH}_{4}^{+}$oxidation than $\mathrm{NH}_{4}^{+}$uptake given that ammonia oxidisers in the winter Southern Ocean become saturated at $\mathrm{NH}_{4}^{+}$concentrations of 100-200 nM (Mdutyana, 2021). The rates reported for the stations north of the SAF should therefore be considered "potential rates". However, since our focus is mainly on explaining the accumulation of $\mathrm{NH}_{4}^{+}$south of the $\mathrm{SAF}$, having potential rather than "true" rates for the STZ and SAZ does not affect our conclusions.

\subsubsection{Plankton community composition}

Microplankton groups $(>15 \mu \mathrm{m})$ were identified and counted in a subsample $(20 \mathrm{~mL})$ from each amber bottle using the Utermöhl technique (Utermöhl, 1958) and following the recommendations of Hasle (1978). Plankton groups and individual species were counted and identified using an inverted light microscope (Olympus CKX41) at 200× magnification. This level of magnification limited the cell sizes that could be reliably distinguished to $>15 \mu \mathrm{m}$. For each sample, at least 100 cells were enumerated to ensure a statistically valid count.
Pico- and nanoplankton cells $(<15 \mu \mathrm{m})$ were enumerated using an LSR II flow cytometer (BD Biosciences) equipped with blue, red, violet, and green lasers. Prior to analysis, $1 \mathrm{~mL}$ of sample was incubated with $1 \%(v / v)$ SYBR Green I (a DNA stain) at room temperature in the dark for $10 \mathrm{~min}$ (Marie et al., 1997). From light scatter and autofluorescence, the DNA-containing particles were identified as nano- and picoeukaryotes, and Synechococcus. Additionally, small heterotrophic prokaryotes (i.e. bacteria and possibly archaea, hereafter "bacteria") were identified as DNA-containing particles with the lowest detectable autofluorescence (Marie et al., 1997; Gasol and del Giorgio, 2000) (see also Sect. S2). All particles lacking DNA were considered detritus. The populations of interest were gated using FlowJo 10.3 software (Tree Star, Inc.; https://www.flowjo.com/, last access: 17 January 2022).

In this study, we did not directly measure $\mathrm{NH}_{4}^{+}$regeneration (i.e. heterotrophy). Instead, we use the abundance of heterotrophic bacteria as a qualitative indicator of $\mathrm{NH}_{4}^{+}$regeneration potential, recognising that cell abundance does not imply activity. Additionally, we estimate the rate of $\mathrm{NH}_{4}^{+}$production from our concentration and rate data (see Sect. 3.3). The availability of organic matter to heterotrophs is inferred from the abundance of detritus.

\subsection{Mixed-layer $\mathrm{NH}_{4}^{+}$residence time and $\mathrm{NH}_{4}^{+}$ production rate estimates}

The residence time of the mixed-layer $\mathrm{NH}_{4}^{+}$pool can be estimated using the measured ambient $\mathrm{NH}_{4}^{+}$concentrations and corresponding $\mathrm{NH}_{4}^{+}$removal rates as

$$
\mathrm{NH}_{4 \text { residence time }}^{+}=\frac{\left[\mathrm{NH}_{4}^{+}\right]}{\mathrm{NH}_{4}^{+} \text {removal rate }} .
$$

Here, $\mathrm{NH}_{4}^{+}$residence time is the time period (days) over which a given $\mathrm{NH}_{4}^{+}$concentration will be depleted assuming a constant $\mathrm{NH}_{4}^{+}$removal rate. We set $\mathrm{NH}_{4}^{+}$removal rate equal to $\rho \mathrm{NH}_{4}^{+}+\mathrm{NH}_{4}^{+}$ox in winter and equal to $\rho \mathrm{NH}_{4}^{+}$in late summer given the evidence for negligible mixed-layer $\mathrm{NH}_{4}^{+}$ oxidation rates in this latter season (Bianchi et al., 1997; Mdutyana et al., 2020).

To determine the contribution of late-summer $\mathrm{NH}_{4}^{+}$production to the wintertime $\mathrm{NH}_{4}^{+}$pool (see Sect. 5.2), we define a rate of $\mathrm{NH}_{4}^{+}$concentration decline:

$\mathrm{NH}_{4}^{+}$rate of decline $=\mathrm{NH}_{4}^{+}$production rate $-\mathrm{NH}_{4 \text { removal rate }}^{+}$.

Here, $\mathrm{NH}_{4}^{+}$production rate is the $\mathrm{NH}_{4}^{+}$flux required to compensate for $\mathrm{NH}_{4}^{+}$removal over the late-summer-to-winter period, in order to yield the observed seasonal change in the ambient $\mathrm{NH}_{4}^{+}$concentration.

The rate of $\mathrm{NH}_{4}^{+}$concentration decline can also be defined as

$\mathrm{NH}_{4}^{+}$rate of decline $=\frac{\left[\mathrm{NH}_{4}^{+}\right]_{\text {decline }}}{t}$, 
where $\left[\mathrm{NH}_{4}^{+}\right]_{\text {decline }}$ is the difference between the latesummer and winter $\mathrm{NH}_{4}^{+}$concentrations and $t$ is the time period (days) over which the $\mathrm{NH}_{4}^{+}$concentration declines. Setting Eqs. (6) and (7) to be equal yields

$\mathrm{NH}_{4}^{+}$production rate $=\frac{\left[\mathrm{NH}_{4}^{+}\right]_{\text {decline }}}{t}+\mathrm{NH}_{4}^{+}$removal rate,

where $\mathrm{NH}_{4}^{+}$removal rate $=\rho \mathrm{NH}_{4}^{+}+\mathrm{NH}_{4}^{+}$ox. Equations (7) and (8) assume that the elevated wintertime $\mathrm{NH}_{4}^{+}$concentrations result from continuous $\mathrm{NH}_{4}^{+}$production in excess of removal rather than from sporadic events of removal and/or production occurring between late summer and winter.

\subsection{Statistical analyses}

The correlations among latitude, $\mathrm{N}$ concentrations, NPP, $\mathrm{N}$ assimilation rates, and $\mathrm{NH}_{4}^{+}$oxidation rates were investigated at the $5 \%$ significance level using the Pearson correlation coefficient and the $\mathrm{R}$ packages stats ( $\mathrm{R}$ Core Team, 2020) and corrplot (Wei and Simko, 2017). Figures were made using the ggplot2 (Wickham, 2016), abind (Plate and Heiberger, 2019), ggpubr (Kassambara, 2019), lubridate (Grolemund and Wickham, 2011), MBA (Finley et al., 2017), metR (Campitelli, 2019), mgcv (Wood, 2017), oce (Kelley and Richards, 2022), and scales (Wickham and Seidel, 2020) $\mathrm{R}$ packages. Standard deviations were propagated using standard statistical practices.

\section{Results}

\subsection{Hydrography}

Sea surface temperature (SST) decreased by $\sim 17^{\circ} \mathrm{C}$ between Cape Town $\left(\sim 34^{\circ} \mathrm{S}\right)$ and the edge of the MIZ $\left(61.7^{\circ} \mathrm{S}\right)$, with similar gradients measured for legs $\mathrm{S}$ and $\mathrm{N}$. During leg N, fairly deep MLDs were observed (124-212 m), which were similar to June and July climatological MLDs compiled from Argo float data for this region (Dong et al., 2008). While the focus of this study is the surface (i.e. upper $\sim 10 \mathrm{~m}$ ), we report the MLDs here to show that sampling took place under typical winter conditions, with the deep MLDs evincing ongoing winter mixing and associated nutrient recharge. Where not specified, the trends discussed below refer to the surface data only. Latitudinal variations in each parameter are assessed by comparing the various Southern Ocean zones - the Subtropical Zone (STZ) north of the Subtropical Front (STF); the Subantarctic Zone (SAZ) between the STF and the Subantarctic Front (SAF), the Polar Frontal Zone (PFZ) between the SAF and the Polar Front (PF); and south of the PF, the Open Antarctic Zone and Polar Antarctic Zone (OAZ and PAZ, which are divided by the Southern Antarctic Circumpolar Current Front (SACCF) and collectively termed the Antarctic Zone (AZ); see Sect. S1 for detailed definitions of the fronts and zones and Figs. 1 and
$\mathrm{S} 1$ for their positions at the time of sampling). For each parameter, the average $\pm 1 \mathrm{SD}$ for each Southern Ocean zone is reported in Table 1.

\subsection{Macronutrient concentrations}

In winter 2017, the surface and mixed-layer concentrations of $\mathrm{NH}_{4}^{+}$ranged from below detection to $0.70 \mu \mathrm{M}$ (Fig. 2a and b). Surface concentrations were higher in the PFZ, OAZ, and PAZ $(0.42 \pm 0.01,0.52 \pm 0.01$, and $0.58 \pm 0.01 \mu \mathrm{M}$, respectively) than in the STZ and SAZ $(0.08 \pm 0.03$ and $0.06 \pm 0.01 \mu \mathrm{M}$, respectively), with a sharp gradient observed at the SAF. South of the SAF, high $\mathrm{NH}_{4}^{+}$concentrations persisted near-homogeneously throughout the mixed layer, with mixed-layer averages ranging from $0.65 \pm 0.01 \mu \mathrm{M}$ at station $58.5^{\circ} \mathrm{S}$ to $0.27 \pm 0.01 \mu \mathrm{M}$ at station $48.0^{\circ} \mathrm{S}$ and averaging $0.47 \pm 0.02 \mu \mathrm{M}$, with concentrations that were below detection north of the SAF (Fig. 2b). Below the mixed layer, $\mathrm{NH}_{4}^{+}$concentrations decreased rapidly at all stations to values below detection by $200 \mathrm{~m}$.

The concentrations of $\mathrm{NO}_{3}^{-}$and $\mathrm{PO}_{4}^{3-}$ increased southwards from $<10$ and $<1 \mu \mathrm{M}$ in the STZ to $>20$ and $>$ $1.5 \mu \mathrm{M}$ in the PFZ, OAZ, and PAZ (Fig. 2c and S3a), with the sharpest gradients occurring near the SAF. The concentrations of $\mathrm{Si}(\mathrm{OH})_{4}$ increased rapidly across the PF, from an average of $3.2 \pm 1.1 \mu \mathrm{M}$ between 35.0 and $48.0^{\circ} \mathrm{S}$ to $45.6 \pm 0.6 \mu \mathrm{M}$ between 52.1 and $58.9^{\circ} \mathrm{S}$ (Fig. S3b). The $\mathrm{NO}_{2}^{-}$concentrations were consistently low across the transect $(0.16 \pm 0.02 \mu \mathrm{M}$; Fig. S3c), as were the concentrations of urea $(0.20 \pm 0.04 \mu \mathrm{M}$; Table 1$)$, with slightly lower urea concentrations observed in the SAZ than in the other zones.

\subsection{Chlorophyll $a$, POC, and PON}

The highest bulk [ $\mathrm{chl} a$ ] was observed near the South African continental shelf, decreasing across the STF and remaining low thereafter (Fig. 3a). The proportion of $\operatorname{chl} a$ in the nano+ size class varied across the region but was $>50 \%$ at all stations, with higher $(>80 \%)$ contributions near the fronts and at many OAZ and PAZ stations (Fig. 3b). The nano+ contribution was $\leq 60 \%$ at only five stations (three in the SAZ, two in the OAZ).

The concentrations of bulk POC and PON were highest north of the STF and slightly higher in the OAZ than in the SAZ and PFZ (Fig. S4a and b). The contributions of the nano+ size fraction to POC and PON across the transect were $77.1 \pm 22.6 \%$ and $66.9 \pm 24.2 \%$, respectively (Fig. S4c and d). The $\delta^{15} \mathrm{~N}-\mathrm{PON}$ decreased southwards from the STZ and SAZ $(1.7 \pm 1.0 \%$ ) to the PFZ and OAZ (0.5 $\pm 0.5 \%$; Fig. 4$)$. Despite considerable differences among zones, the $\delta^{15} \mathrm{~N}-\mathrm{PON}$ was relatively homogenous within each zone. 
Table 1. Mean ( \pm 1 SD) of surface ocean POC, PON, chl $a$, and nutrient concentrations, cell abundances, and nutrient uptake rates measured in each zone of the Southern Ocean in winter 2017. Where no SD is given, only one sample was measured. The $>0.3 \mu \mathrm{M}$ and $>2.7 \mu \mathrm{m}$ size fractions are referred to as bulk and nano+, respectively. "\% of nano+" refers to the average relative contribution of the nano+ size fraction to total chl $a$, POC, or PON, calculated for each station within a zone. The $f$ ratio including $\rho$ Urea is shown only for zones where $\rho$ Urea was measured at all stations. "ND" indicates no data available. Abbreviations are as in Fig. 1.

\begin{tabular}{|c|c|c|c|c|c|}
\hline & STZ & SAZ & PFZ & OAZ & PAZ \\
\hline $\mathrm{NH}_{4}^{+}(\mu \mathrm{M})$ & $0.08 \pm 0.03$ & $0.06 \pm 0.01$ & $0.42 \pm 0.01$ & $0.52 \pm 0.01$ & $0.58 \pm 0.01$ \\
\hline $\mathrm{PO}_{4}^{3-}(\mu \mathrm{M})$ & $0.44 \pm 0.07$ & $0.90 \pm 0.06$ & $1.59 \pm 0.1$ & $2.00 \pm 0.13$ & $1.99 \pm 0.09$ \\
\hline $\mathrm{NO}_{3}^{-}(\mu \mathrm{M})$ & $3.6 \pm 0.2$ & $10.5 \pm 0.5$ & $21.5 \pm 0.2$ & $26.7 \pm 0.4$ & $27.5 \pm 0.4$ \\
\hline $\mathrm{Si}(\mathrm{OH})_{4}(\mu \mathrm{M})$ & $2.6 \pm 0.1$ & $2.5 \pm 1.8$ & $6.6 \pm 0.1$ & $40.3 \pm 0.5$ & $45.0 \pm 0.8$ \\
\hline $\mathrm{NO}_{2}^{-}(\mu \mathrm{M})$ & $0.15 \pm 0.02$ & $0.13 \pm 0.02$ & $0.17 \pm 0.02$ & $0.19 \pm 0.01$ & $0.21 \pm 0.02$ \\
\hline Urea $(\mu \mathrm{M})$ & $0.23 \pm 0.04$ & $0.11 \pm 0.04$ & $0.26 \pm 0.08$ & 0.24 & $0.21 \pm 0.03$ \\
\hline $\operatorname{chl} a$ (bulk) $\left(\mu \mathrm{g} \mathrm{L}^{-1}\right)$ & $0.65 \pm 0.08$ & $0.43 \pm 0.05$ & $0.35 \pm 0.03$ & $0.25 \pm 0.02$ & $0.21 \pm 0.00$ \\
\hline $\operatorname{chl} a($ nano +$)\left(\mu \mathrm{g} \mathrm{L}^{-1}\right)$ & $0.50 \pm 0.05$ & $0.30 \pm 0.04$ & $0.24 \pm 0.02$ & $0.18 \pm 0.02$ & $0.17 \pm 0.02$ \\
\hline $\operatorname{chl} a($ pico $)\left(\mu \mathrm{g} \mathrm{L}^{-1}\right)$ & $0.15 \pm 0.1$ & $0.13 \pm 0.07$ & $0.11 \pm 0.04$ & $0.06 \pm 0.03$ & $0.04 \pm 0.02$ \\
\hline $\operatorname{chl} a(\%$ of nano +$)$ & $77.5 \pm 13.9$ & $73.1 \pm 10.9$ & $69.8 \pm 8.7$ & $76.7 \pm 11.3$ & $80.1 \pm 8.5$ \\
\hline POC (bulk) $(\mu \mathrm{M})$ & $4.4 \pm 6.7$ & $3.4 \pm 0.4$ & $3.2 \pm 0.3$ & $3.4 \pm 0.5$ & $3.5+0.2$ \\
\hline POC $($ nano+ +$)(\mu \mathrm{M})$ & $2.6 \pm 0.5$ & $2.6 \pm 0.4$ & $1.9 \pm 1.2$ & $1.9 \pm 0.4$ & 4.6 \\
\hline PON (bulk) $(\mu \mathrm{M})$ & $0.6 \pm 0.2$ & $0.5 \pm 0.1$ & $0.4 \pm 0.1$ & $0.5 \pm 0.1$ & $0.5 \pm 0.1$ \\
\hline PON $($ nano +$)(\mu \mathrm{M})$ & $0.3 \pm 0.1$ & $0.3 \pm 0.1$ & $0.2 \pm 0.3$ & $0.2 \pm 0.1$ & $0.4 \pm 0.0$ \\
\hline POC (\% of nano+) & $79.7 \pm 24.6$ & $79.6 \pm 19.0$ & $50.9 \pm 33.2$ & $77.2 \pm 21.8$ & ND \\
\hline PON ( $\%$ of nano +$)$ & $69.0 \pm 31.9$ & $67.1 \pm 17.2$ & $53.8 \pm 24.1$ & $67.0 \pm 21.9$ & $51.1 \pm 24.7$ \\
\hline POC : chl $a\left(\mathrm{~g} \mathrm{~g}^{-1}\right)$ & $103.0 \pm 22.1$ & $102.5 \pm 14.4$ & $122.5 \pm 11$ & $234.1 \pm 29.2$ & $219.3 \pm 1.0$ \\
\hline POC : PON $\left(\mathrm{M} \mathrm{M}^{-1}\right)$ & $7.81 \pm 6.49$ & $6.90 \pm 1.25$ & $7.13 \pm 0.71$ & $6.72 \pm 1.62$ & $5.80 \pm 3.75$ \\
\hline$\delta^{15} \mathrm{~N}-\mathrm{PON}$ & $1.4 \pm 0.9$ & $1.2 \pm 1.0$ & $0.3 \pm 0.5$ & $-1.3 \pm 0.5$ & $-1.3 \pm 0.4$ \\
\hline NPP (bulk) (nM d $\left.d^{-1}\right)$ & $497.1 \pm 42.4$ & $277.5 \pm 21.3$ & $289.7 \pm 19.2$ & $85.3 \pm 26.1$ & $27.7 \pm 0.2$ \\
\hline $\mathrm{NPP}($ nano+ $)\left(\mathrm{nM} \mathrm{d}^{-1}\right)$ & $384.7 \pm 29.7$ & $178.2 \pm 23.4$ & 193.5 & $49.6 \pm 5.0$ & ND \\
\hline$\rho \mathrm{NH}_{4}^{+}$(bulk) $\left(\mathrm{nMd}^{-1}\right)$ & $5.7 \pm 0.8$ & $8.9 \pm 1.1$ & $12.9 \pm 0.4$ & $4.8 \pm 0.1$ & $3.0 \pm 0.8$ \\
\hline$\rho \mathrm{NH}_{4}^{+}($nano+ $)\left(\mathrm{nMd}^{-1}\right)$ & $4.0 \pm 1.1$ & $4.1 \pm 1.2$ & $4.2 \pm 4.7$ & $3.1 \pm 0.4$ & ND \\
\hline$\rho \mathrm{NO}_{3}^{-}$(bulk) $\left(\mathrm{nMd}^{-1}\right)$ & $4.1 \pm 0.4$ & $11.5 \pm 1.4$ & $5.9 \pm 1$ & $3.6 \pm 0.4$ & $3.7 \pm 1.8$ \\
\hline$\rho \mathrm{NO}_{3}^{-}($nano +$)\left(\mathrm{nMd}^{-1}\right)$ & $3.4 \pm 0.3$ & $6.6 \pm 0.4$ & $4.3 \pm 0.4$ & $2.6 \pm 0.8$ & $2.7 \pm 1.2$ \\
\hline$\rho$ Urea (bulk) $\left(\mathrm{nM} \mathrm{d}^{-1}\right)$ & $7.5 \pm 0.6$ & $6.9 \pm 0.3$ & $6.5 \pm 1.0$ & $2.1 \pm 0.3$ & $0.6 \pm 0.01$ \\
\hline$\rho$ Urea $($ nano +$)\left(\mathrm{nM} \mathrm{d}^{-1}\right)$ & $4.9 \pm 0.3$ & $3.8 \pm 0.2$ & $4.0 \pm 0.6$ & $1.3 \pm 0.2$ & $0.7 \pm 0.4$ \\
\hline$f$ ratio (bulk) (including $\rho$ Urea) & $0.21 \pm 0.31$ & $0.43 \pm 0.11$ & $0.23 \pm 0.18$ & ND & $0.51 \pm 0.53$ \\
\hline$f$ ratio (bulk) (excluding $\rho$ Urea) & $0.43 \pm 0.32$ & $0.57 \pm 0.12$ & $0.31 \pm 0.18$ & $0.43 \pm 0.16$ & $0.55 \pm 0.54$ \\
\hline $\mathrm{NH}_{4}^{+} \mathrm{ox}\left(\mathrm{nMd}^{-1}\right)$ & $9.3 \pm 0.5$ & $12.9 \pm 0.6$ & 11.1 & $17.7 \pm 0.6$ & $14.3 \pm 1.0$ \\
\hline Total microplankton (cells $\mathrm{mL}^{-1}$ ) & $13 \pm 11$ & $5 \pm 3$ & $9 \pm 3$ & $6 \pm 6$ & $4 \pm 2$ \\
\hline Centric diatoms (cells $\mathrm{mL}^{-1}$ ) & $<1$ & $<1$ & $<1$ & $<1$ & $1 \pm 2$ \\
\hline Pennate diatoms (cells $\mathrm{mL}^{-1}$ ) & $2 \pm 4$ & $<1$ & $2 \pm 1$ & $2 \pm 3$ & $<1$ \\
\hline Dinoflagellates (cells $\mathrm{mL}^{-1}$ ) & $7 \pm 6$ & $4 \pm 0$ & $6 \pm 2$ & $3 \pm 2$ & $2 \pm 0$ \\
\hline Microzooplankton (cells $\mathrm{mL}^{-1}$ ) & $4 \pm 3$ & $<1$ & $2 \pm 2$ & $1 \pm 2$ & $<1$ \\
\hline Nanoeukaryotes (cells mL ${ }^{-1}$ ) & ND & $2.2 \pm 1.4 \times 10^{3}$ & $1.5 \pm 0.7 \times 10^{3}$ & $1.6 \pm 0.7 \times 10^{3}$ & $1.4 \times 10^{3}$ \\
\hline Picoeukaryotes (cells mL ${ }^{-1}$ ) & ND & $4.5 \pm 2.9 \times 10^{3}$ & $4.9 \pm 3.7 \times 10^{3}$ & $1.5 \pm 0.5 \times 10^{3}$ & $8 \times 10^{2}$ \\
\hline Synechococcus $\left(\right.$ cells $\left.\mathrm{mL}^{-1}\right)$ & ND & $3.8 \pm 1.8 \times 10^{3}$ & $2.3 \pm 1.1 \times 10^{3}$ & $1.4 \pm 0.2 \times 10^{3}$ & $1 \times 10^{3}$ \\
\hline Heterotrophic prokaryotes (cells $\mathrm{mL}^{-1}$ ) & ND & $4.5 \pm 3.2 \times 10^{3}$ & $2.3 \pm 1.2 \times 10^{3}$ & $2.1 \pm 2.3 \times 10^{3}$ & $3.2 \times 10^{3}$ \\
\hline Detritus (particles $\mathrm{mL}^{-1}$ ) & ND & $38.2 \pm 14.9 \times 10^{3}$ & $63.8 \pm 42.9 \times 10^{3}$ & $25.7 \pm 18.6 \times 10^{3}$ & $2.57 \times 10^{4}$ \\
\hline
\end{tabular}


(a)

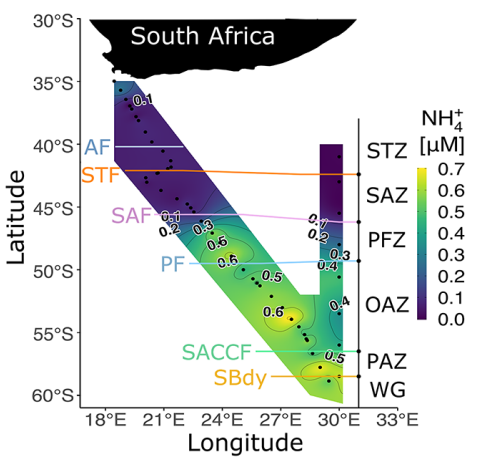

(b)

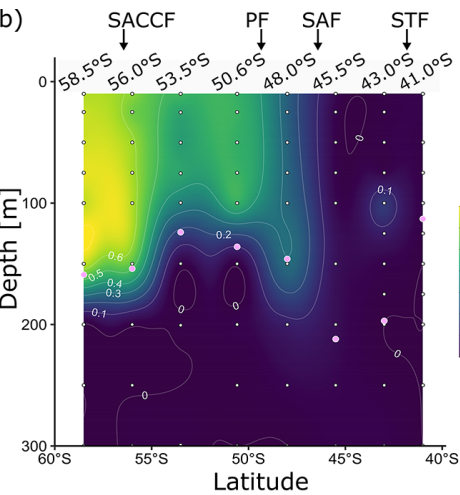

(c)

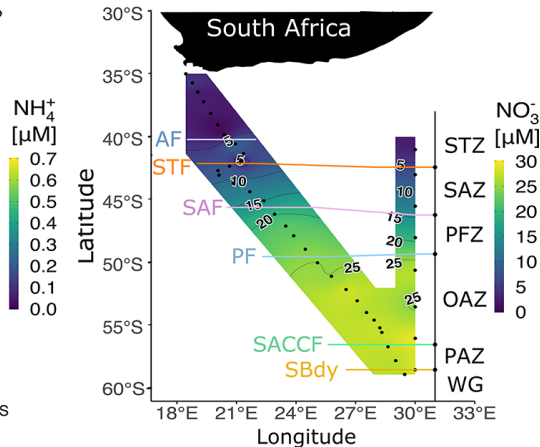

Figure 2. Concentrations of dissolved ammonium $\left(\mathrm{NH}_{4}^{+}\right)$(a) at the surface for legs $\mathrm{S}$ and $\mathrm{N}$ and (b) with depth $(0-300 \mathrm{~m})$ for leg $\mathrm{N}$, and (c) concentrations of nitrate $\left(\mathrm{NO}_{3}^{-}\right)$at the surface for legs $\mathrm{S}$ and $\mathrm{N}$. Pink circles in (b) show the mixed-layer depth at the CTD stations. Abbreviations are as in Fig. 1. Figure produced using the package ggplot2 (Wickham, 2016).
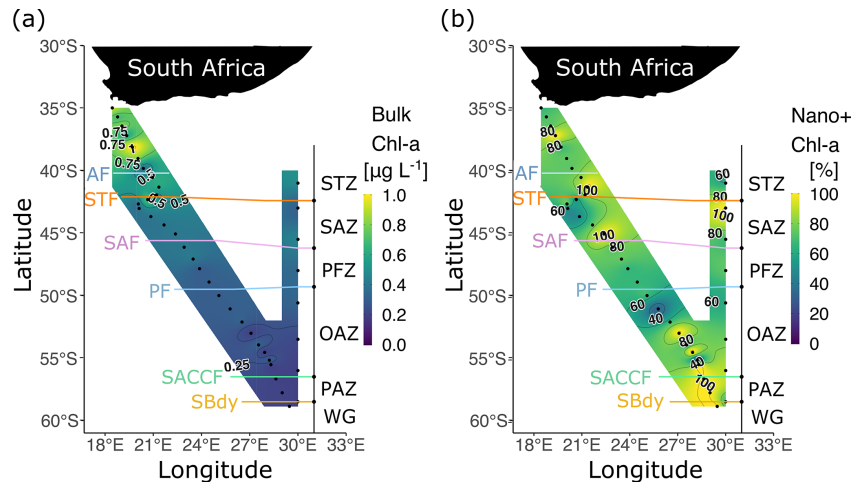

Figure 3. (a) Bulk chlorophyll $a(\operatorname{chl} a)$ concentrations and (b) the proportion of chlorophyll $a$ in the nano+ size fraction at the surface for legs $\mathrm{S}$ and N. Abbreviations are as in Fig. 1. Figure produced using the package ggplot2 (Wickham, 2016).

\subsection{Rates of net primary production, nitrogen uptake, and ammonium oxidation}

Rates of bulk NPP were 2- to 6-fold higher in the SAZ and PFZ than has been reported previously for the Atlantic sector in winter (Mdutyana et al., 2020; Froneman et al., 1999) (Fig. 5a). By contrast, NPP was low in the OAZ, consistent with previous measurements (Kottmeier and Sullivan, 1987; Mdutyana et al., 2020). The relative contribution of the nano+ size class generally decreased southwards, from $85.4 \%$ at $37.0^{\circ} \mathrm{S}$ to $24.4 \%$ at $53.5^{\circ} \mathrm{S}$, before increasing to $>80 \%$ near the SACCF.

The bulk $\mathrm{NH}_{4}^{+}$uptake rates $\left(\rho \mathrm{NH}_{4}^{+}\right)$generally increased southwards from the STZ to the SAZ and PFZ and then decreased across the OAZ to reach a minimum at the southernmost station (Fig. 5b). In the nano+ size fraction, $\rho \mathrm{NH}_{4}^{+}$ changed little latitudinally, although it was slightly lower in the OAZ than in the other zones. The contribution of nanoplankton to $\rho \mathrm{NH}_{4}^{+}$ranged from $32.8 \%$ in the PFZ to

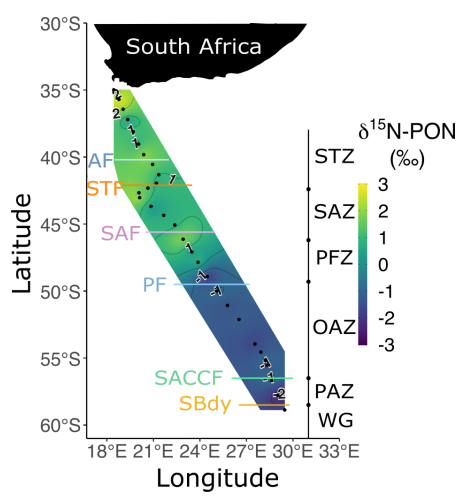

Figure 4. Bulk $\delta^{15} \mathrm{~N}-\mathrm{PON}$ at the surface for leg $\mathrm{S}$ in winter 2017. The two stations nearest South Africa at which biomass concentrations were extremely high have been excluded. Abbreviations are as in Fig. 1. Figure produced using the package ggplot2 (Wickham, 2016).

$71.9 \%$ in the STZ. The bulk $\mathrm{NO}_{3}^{-}$uptake rates $\left(\rho \mathrm{NO}_{3}^{-}\right)$ were also low in the STZ, while the highest $\rho \mathrm{NO}_{3}^{-}$was measured in the SAZ, with the rate then decreasing southwards. $\rho \mathrm{NO}_{3}^{-}$in the nano+ size class followed the same trend as total community $\rho \mathrm{NO}_{3}^{-}$, with the nanoplankton accounting for $71.5 \pm 0.3 \%$ of bulk $\rho \mathrm{NO}_{3}^{-}$on average. The rates of bulk urea uptake ( $\rho$ Urea) were highest in the STZ, with the SAZ and the PFZ hosting similar rates, and the lowest rates were measured in the OAZ. $\rho$ Urea for the nano+ size class followed a similar trend to bulk $\rho$ Urea, and nanoplankton accounted for $51.8 \%$ of $\rho$ Urea in the SAZ, increasing to $66.1 \%$ in the STZ. The uptake rates of the different $\mathrm{N}$ forms were not significantly correlated with one another or with the ambient $\mathrm{N}$ concentrations (Table S1).

Ammonium oxidation rates $\left(\mathrm{NH}_{4}^{+}\right.$ox $)$increased southwards, with higher $\mathrm{NH}_{4}^{+}$ox in the $\mathrm{OAZ}$ and PAZ than in the STZ, SAZ, and PFZ (Fig. 5c). $\mathrm{NH}_{4}^{+}$ox was generally comparable to previous wintertime measurements from the surface 

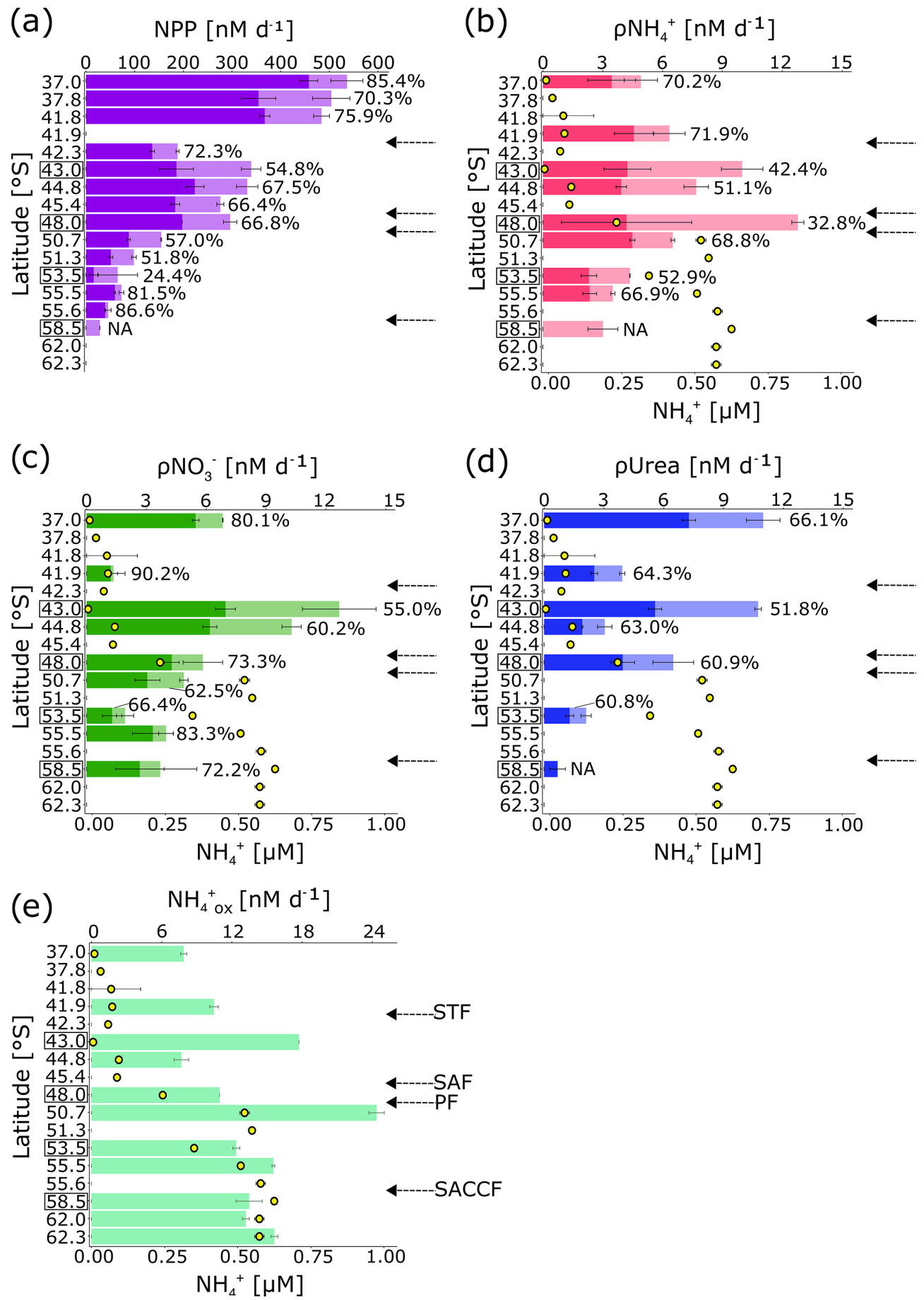

Figure 5. (a) Surface rates of net primary production (NPP); rates of (b) ammonium $\left(\rho \mathrm{NH}_{4}^{+}\right)$, (c) nitrate $\left(\rho \mathrm{NO}_{3}^{-}\right)$, and (d) urea $(\rho \mathrm{Urea})$ uptake by the pico (light colours) and nano+ (dark colours) size fractions, with the full length of the bars indicating the bulk rates; and (e) rates of $\mathrm{NH}_{4}^{+}$oxidation. Error bars indicate \pm 1 standard deviation of duplicate experiments. The percentage of total NPP and $\mathrm{N}$ uptake attributable to the nano+ size fraction is written next to each bar in (a-d). NPP and $\mathrm{NH}_{4}^{+}$uptake were not measured for the nano+ size fraction at $58.5^{\circ} \mathrm{S}$, and urea uptake was not measured at 50.7 and $55.5^{\circ} \mathrm{S}$. Rates were not measured at the latitudes where no data are shown. In (b-e) the surface $\mathrm{NH}_{4}^{+}$concentration at each station is shown by the yellow circles. Leg $\mathrm{N}$ stations (at which samples were collected from Niskin bottles fired at $10 \mathrm{~m}$ ) are indicated by black boxes surrounding the latitude. By contrast, samples were collected at the leg $\mathrm{S}$ stations (no square surrounding the latitude) from the ship's underway system $(\sim 7 \mathrm{~m})$. Fronts are indicated with arrows (labelled in e), and abbreviations are as in Fig. 1. Figure produced using the package ggplot2 (Wickham, 2016). 
(a)

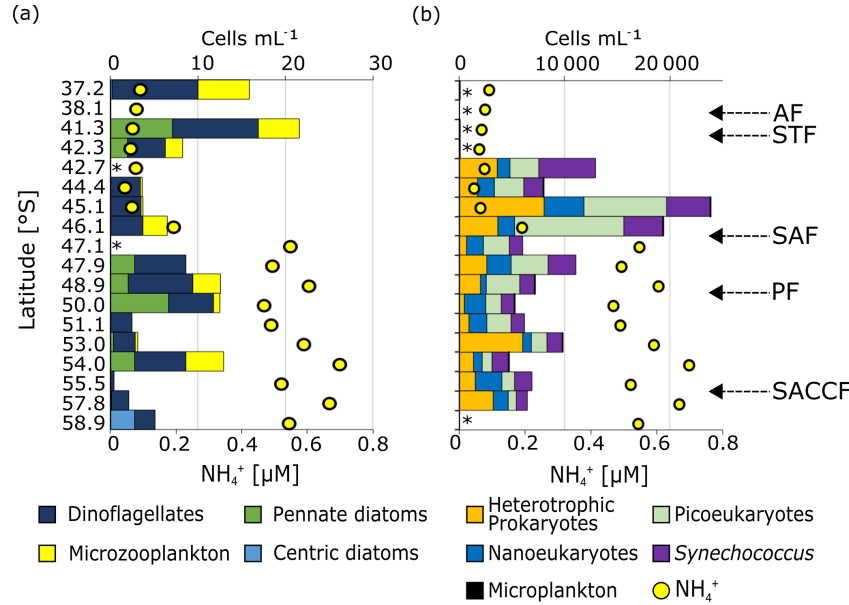

Figure 6. Surface community composition for (a) plankton $\geq 15 \mu \mathrm{m}$ (enumerated by microscopy) and (b) the total community $<15 \mu \mathrm{m}$ (enumerated by flow cytometry). For context, the surface $\mathrm{NH}_{4}^{+}$concentration at each station is shown by the yellow circles. ${ }^{*}$ indicates stations at which no measurements were made while the absence of a bar with no ${ }^{*}$ indicates that no cells were detected. Note that the abundances shown in (b) (top $x$ axis) are $>2$ orders of magnitude greater than those shown in (a). The "microplankton" shown in (a) are included on (b) (slim black bars) to illustrate the difference in abundance between the micro- and pico+nano populations. The frontal positions are indicated on (b), with abbreviations as in Fig. 1.

of the open Southern Ocean (Mdutyana et al., 2020). $\mathrm{NH}_{4}^{+}$ox was not correlated with the ambient $\mathrm{NH}_{4}^{+}$concentration (Table S1).

\subsection{Plankton community composition}

Microplankton abundance was low, with the highest cell counts recorded at stations 37.2 and $41.3^{\circ} \mathrm{S}$ in the STZ and no cells counted at $38.1^{\circ} \mathrm{S}(\mathrm{STZ})$ and $55.5^{\circ} \mathrm{S}(\mathrm{OAZ})$ (Fig. 6a). On average, microplankton abundance was higher in the STZ than in the SAZ, PFZ, and OAZ. The greatest diversity of microplankton groups was observed at $41.3^{\circ} \mathrm{S}$ in the $\mathrm{STZ}$ and at $50.0^{\circ} \mathrm{S}$ near the $\mathrm{PF}$.

Centric diatoms (including Planktoniella, Coscinodiscus, and Thalassiosira species) were detected only at the southernmost station $58.9^{\circ} \mathrm{S}$ ( 3 cells $\mathrm{mL}^{-1}$ ). Pennate diatoms (including Pseudo-nitzschia, Pleurosigma, and Navicula species) were more abundant in the STZ, PFZ, and OAZ, with negligible abundances in the SAZ. Higher pennate diatom abundances occurred near the PF $\left(7\right.$ cells $\mathrm{mL}^{-1}$ ), as has been observed in summer (e.g. Bracher et al., 1999). Dinoflagellates were identified at every station except $38.1^{\circ} \mathrm{S}$ and were most abundant in the STZ and PFZ. At all but three stations, small $(\sim 15 \mu \mathrm{m})$ dinoflagellates were the most abundant group, although the larger Protoperidinium dinoflagellate species (mainly heterotrophic; Jeong and Latz, 1994) were almost as abundant in the PFZ and at $54.0^{\circ} \mathrm{S}$. Mi- crozooplankton (i.e. ciliates, $20-200 \mu \mathrm{M}$ ) were most abundant in the STZ and were also present in the PFZ at $46.1^{\circ} \mathrm{S}$ ( 3 cells $\mathrm{mL}^{-1}$ ) and $48.9^{\circ} \mathrm{S}\left(3\right.$ cells $\left.\mathrm{mL}^{-1}\right)$ and in the $\mathrm{OAZ}$ at $\left.50.0^{\circ} \mathrm{S}(1 \text { cell mL})^{-1}\right)$ and $54.0^{\circ} \mathrm{S}\left(4\right.$ cells $\left.\mathrm{mL}^{-1}\right)$. All other stations were characterised by negligible $\left(<1\right.$ cell $\left.\mathrm{mL}^{-1}\right) \mathrm{mi}-$ crozooplankton abundances.

Nano- and picoeukaryotes, Synechococcus, and heterotrophic bacteria (collectively, "small cells") were roughly $10^{3}$ times more abundant than the microplankton (Fig. 6b). Notwithstanding a lack of data from the STZ, the highest small-cell abundances occurred in the SAZ near the SAF. Across the transect, picoeukaryotes were generally more abundant than all other phytoplankton groups (average contribution to total small cells of $12 \%-54 \%$ for picoeukaryotes, $7 \%-39 \%$ for nanoeukaryotes, and $15 \%-42 \%$ for Synechococcus). A similar trend has been observed for the Southern Ocean in spring (Detmer and Bathmann, 1997) and late summer (Fiala et al., 1998), in contrast to midsummer observations showing nanoplankton dominance (e.g. Ishikawa et al., 2002; Weber and El-Sayed, 1987). Additionally, picoeukaryotes were 2 to 3 orders of magnitude more abundant in the SAZ and PFZ than in the OAZ. Nanoeukaryotes dominated near the $\mathrm{PF}$ at $50.0^{\circ} \mathrm{S}(39 \%)$ and in the southern OAZ at $55.5^{\circ} \mathrm{S}(36 \%)$, while Synechococcus dominated at 42.7 and $54.0^{\circ} \mathrm{S}$ ( $42 \%$ and $33 \%$, respectively). In general, nanoeukaryote abundance was higher in the SAZ than in the PFZ and OAZ, as was that of Synechococcus.

The contribution of heterotrophic bacteria to the total small cells varied considerably $(10 \%-62 \%)$, reaching a maximum south of the PF at 53.0 and $57.8^{\circ} \mathrm{S}(62 \%$ and $50 \%$ ) and with higher abundances in the SAZ than in the PFZ and OAZ (Fig. 7). Additionally, heterotrophic bacterial abundances were 10-fold lower to 2-fold higher than the total pico- and nanophytoplankton cell counts. Detrital particles were most abundant near the southern edge of the SAF and were generally more abundant in the PFZ than in the SAZ and OAZ (Fig. S5).

\subsection{8-2019 cruises - ammonium concentrations}

In early summer, surface $\mathrm{NH}_{4}^{+}$concentrations were uniformly low across the transect (average of $0.11 \pm 0.09 \mu \mathrm{M}$; Fig. 8a). South of the SAF, $\mathrm{NH}_{4}^{+}$increased to an average concentration of $0.81 \pm 0.92 \mu \mathrm{M}$ by late summer (Fig. 8b). By winter 2019, the $\mathrm{NH}_{4}^{+}$concentrations south of the SAF were $\sim 40 \%$ lower than they had been in late summer (Fig. 8c), and they were similar to those observed in winter 2017 $(0.50 \pm 0.30$ and $0.52 \pm 0.11 \mu \mathrm{M}$, respectively), confirming that our 2017 observations are generally representative of the wintertime Southern Ocean. By early spring, the $\mathrm{NH}_{4}^{+}$ concentrations south of the SAF had declined to near or below detection $(0.09 \pm 0.08 \mu \mathrm{M}$; Fig. 8d) before rising again by late spring to an average value only slightly lower than that measured in winter $(0.40 \pm 0.74 \mu \mathrm{M}$; Fig. 8e). However, the late-spring $\mathrm{NH}_{4}^{+}$concentrations were elevated only in 


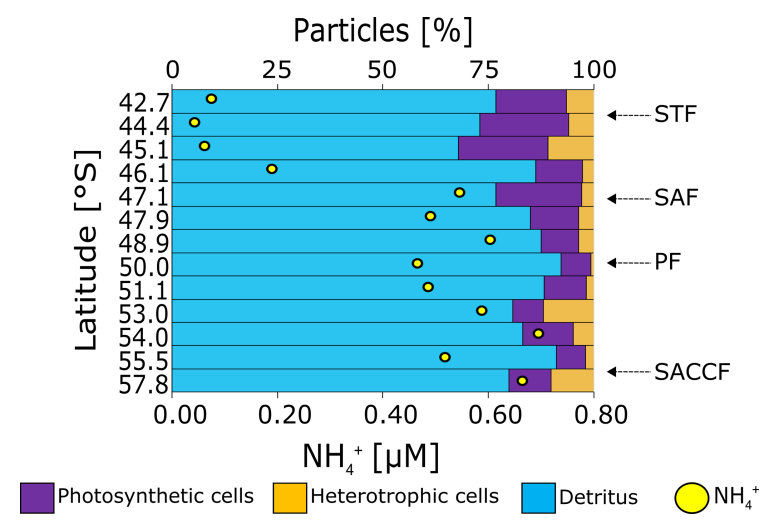

Figure 7. Relative contributions of photosynthetic, heterotrophic bacterial, and detrital particles to the total flow cytometry counts at the surface during leg $\mathrm{S}$. The coincident $\mathrm{NH}_{4}^{+}$concentrations are shown as yellow dots. Abbreviations are as in Fig. 1.

the PFZ (range of $0.11 \pm 0.01$ to $4.39 \pm 0.03 \mu \mathrm{M}$, average of $0.77 \pm 1.11 \mu \mathrm{M}$ ), as has been observed previously (Bathmann et al., 1997). Excluding the PFZ data yields a far lower latespring average of $0.17 \pm 0.11 \mu \mathrm{M}$ south of the SAF, which we take as more broadly representative of this season.

\subsection{Mixed-layer $\mathrm{NH}_{4}^{+}$residence time and $\mathrm{NH}_{4}^{+}$ production rate estimates}

The $\mathrm{NH}_{4}^{+}$residence time in winter 2017, computed using Eq. (5), ranged from 10 to $38 \mathrm{~d}$ (median of $21 \mathrm{~d}$ ) south of the SAF and from 0 to $6 \mathrm{~d}$ (median of $2 \mathrm{~d}$ ) north of the SAF. These values were estimated using wintertime measurements only and, as such, may not be representative of the transition from summer to winter. To refine our estimates, we used average $\rho \mathrm{NH}_{4}^{+}$and $\mathrm{NH}_{4}^{+}$concentration measurements. South of the SAF in late summer, $\rho \mathrm{NH}_{4}^{+}=50.6 \pm 24.0 \mathrm{nM} \mathrm{d}^{-1}$ and the $\mathrm{NH}_{4}^{+}$concentration was $0.81 \pm 0.92 \mu \mathrm{M}$ (Deary, 2020), which together yield an $\mathrm{NH}_{4}^{+}$residence time of 2 to $27 \mathrm{~d}$ (median of $5 \mathrm{~d}$ ). The $\mathrm{NH}_{4}^{+}$residence time north of the $\mathrm{SAF}$, calculated using $\rho \mathrm{NH}_{4}^{+}=20.7 \pm 8.6 \mathrm{nMd}^{-1}$ and an $\mathrm{NH}_{4}^{+}$concentration of $0.16 \pm 0.45 \mu \mathrm{M}$ (Deary, 2020) was 1 to $17 \mathrm{~d}$ (median of $14 \mathrm{~d})$.

The $\mathrm{NH}_{4}^{+}$production rate south of the SAF, calculated using Eq. (8) and an $\left[\mathrm{NH}_{4}^{+}\right]_{\text {decline }}$ of $330 \mathrm{nM}$ (i.e. the difference between late summer and winter $2019,810-480 \mathrm{nM}), t$ of $141 \mathrm{~d}$, and $\mathrm{NH}_{4}^{+}$removal rate of $50.6 \pm 24.0 \mathrm{nM} \mathrm{d}^{-1}$ (here, the average late-summer $\rho \mathrm{NH}_{4}^{+}$south of the SAF is used to approximate $\mathrm{NH}_{4}^{+}$removal rate), was $52.9 \pm 25.0 \mathrm{nM} \mathrm{d}^{-1}$. Similarly, north of the SAF (using an $\left[\mathrm{NH}_{4}^{+}\right]_{\text {decline }}$ of $20 \mathrm{nM}$, i.e. $160-140 \mathrm{nM}$, and $\mathrm{NH}_{4}^{+}$removal rate of $20.7 \pm 8.6 \mathrm{nM} \mathrm{d}^{-1}$ ), the $\mathrm{NH}_{4}^{+}$production rate was $50.7 \pm 9.3 \mathrm{nMd}^{-1}$. If we instead use the average $\mathrm{NH}_{4}^{+}$removal rate and $\mathrm{NH}_{4}^{+}$concentration measured in winter 2017 south $\left(21.4 \pm 0.6 \mathrm{nM} \mathrm{d}^{-1}\right.$ and $520 \pm 110 \mathrm{nM})$ and north $\left(18.4 \pm 0.8 \mathrm{nMd}^{-1}\right.$ and $80 \pm 10 \mathrm{nM}$ ) of the $\mathrm{SAF}$, the $\mathrm{NH}_{4}^{+}$production rate values were
$23.4 \pm 6.6$ and $18.5 \pm 6.6 \mathrm{nMd}^{-1}$, respectively. Using the range of $\mathrm{NH}_{4}^{+}$removal rate estimates and the average ambient $\mathrm{NH}_{4}^{+}$concentration measured south of the $\mathrm{SAF}$ in winter 2017 (16.7 to $31.2 \mathrm{nMd}^{-1}$ and $520 \mathrm{nM}$ ) and late summer 2019 ( 22.6 to $98.6 \mathrm{nM} \mathrm{d}^{-1}$ and $810 \mathrm{nM}$ ), we calculate that over the late-summer-to-winter transition, the $\mathrm{NH}_{4}^{+}$production rate ranged from 18.8 to $100.9 \mathrm{nMd}^{-1}$ (compared to 6.3 to $28.8 \mathrm{nM} \mathrm{d}^{-1}$ north of the $\mathrm{SAF}$ ).

\section{Discussion}

\subsection{Drivers of $\mathrm{NH}_{4}^{+}$cycling in the surface layer of the Southern Ocean}

Previous work has suggested that $\mathrm{NH}_{4}^{+}$accumulates in the Southern Ocean mixed layer following the late-summer increase in heterotrophy and then decreases into autumn as heterotrophic activity subsides, to be depleted by winter due to advective processes and biological removal (Koike et al., 1986; Serebrennikova and Fanning, 2004). However, our data show that $\mathrm{NH}_{4}^{+}$concentrations are elevated in the mixed layer in winter, particularly south of the SAF (Fig. 2). Similarly elevated winter surface-layer $\mathrm{NH}_{4}^{+}$has been observed previously in both the Atlantic and the Indian sectors, with concentrations typically increasing towards the south (Philibert et al., 2015; Mdutyana et al., 2020; Bianchi et al., 1997). Numerous overlapping processes are likely involved in setting the ambient $\mathrm{NH}_{4}^{+}$concentrations, as summarised in Fig. 9. In this study, we directly measured the rates of $\mathrm{NH}_{4}^{+}$ uptake and oxidation and estimated the rates of $\mathrm{NH}_{4}^{+}$production, along with qualitatively evaluating the role of heterotrophy from the relative abundance of heterotrophic bacteria, phytoplankton, and detritus. For the $\mathrm{NH}_{4}^{+}$cycle processes shown in Fig. 9 that are not quantified or inferred from our dataset, we consider their potential role in Southern Ocean $\mathrm{NH}_{4}^{+}$cycling based on findings reported in the literature.

The high $\mathrm{NH}_{4}^{+}$concentrations observed south of the SAF in winter may result from net $\mathrm{NH}_{4}^{+}$accumulation during late summer, autumn, and/or winter. The persistence of elevated $\mathrm{NH}_{4}^{+}$concentrations that are near-homogeneously distributed throughout the mixed layer is consistent with a residence time for the winter $\mathrm{NH}_{4}^{+}$reservoir in excess of the timescale for upper-ocean mixing. Indeed, we calculate a median residence time of $21 \mathrm{~d}$ south of the SAF, compared to $2 \mathrm{~d}$ north of the SAF. One implication of the long residence time computed for the polar zones is that the wintertime $\mathrm{NH}_{4}^{+}$ pool likely reflects both ongoing processes and those that occurred earlier in the year. We posit that the elevated $\mathrm{NH}_{4}^{+}$ concentrations south of the SAF may result from higher wintertime rates of $\mathrm{NH}_{4}^{+}$production than removal and/or from the gradual but incomplete depletion in winter of $\mathrm{NH}_{4}^{+}$produced mainly in late summer and autumn. We evaluate both possibilities throughout the discussion below. 

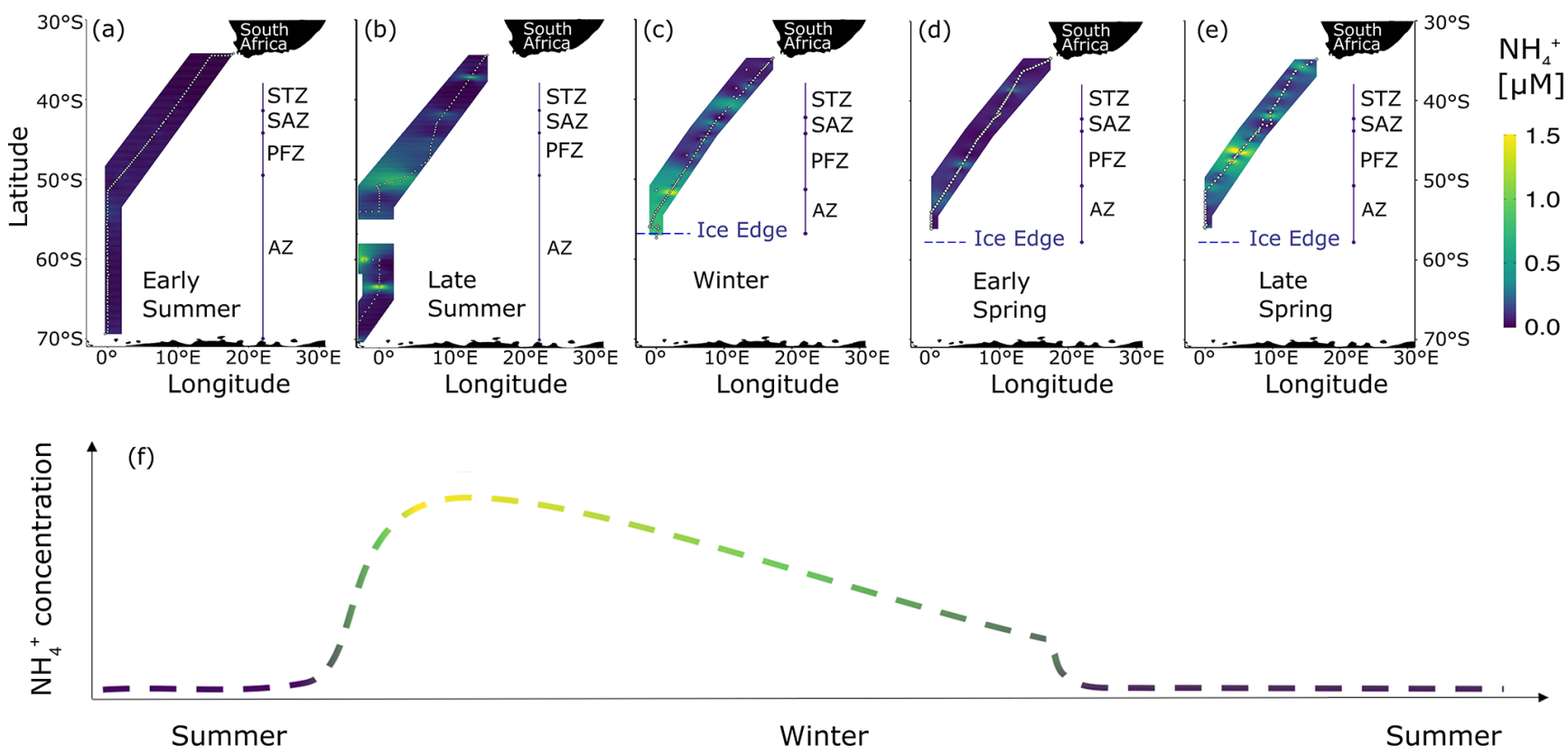

Figure 8. Surface concentrations of $\mathrm{NH}_{4}^{+}$across the eastern Atlantic sector of the Southern Ocean measured between December 2018 and November 2019. Five unique transects (additional to the winter 2017 dataset presented in Fig. 2a) are shown: (a) early summer 2018, (b) late summer 2019, (c) winter 2019, (d) early spring 2019, and (e) late spring 2019. (f) The proposed seasonal cycle of $\mathrm{NH}_{4}^{+}$concentrations in the mixed layer south of the Subantarctic Front. The colour gradient in (f) shows the transition between late summer and late winter. Panels (a, b) cover a latitudinal extent of $30-70^{\circ} \mathrm{S}$, while panels (c-e) cover $30-60^{\circ} \mathrm{S}$ due to the presence of sea ice. Abbreviations are as in Fig. 1 , with AZ referring to the combined OAZ and PAZ. Figure produced using the package ggplot2 (Wickham, 2016).

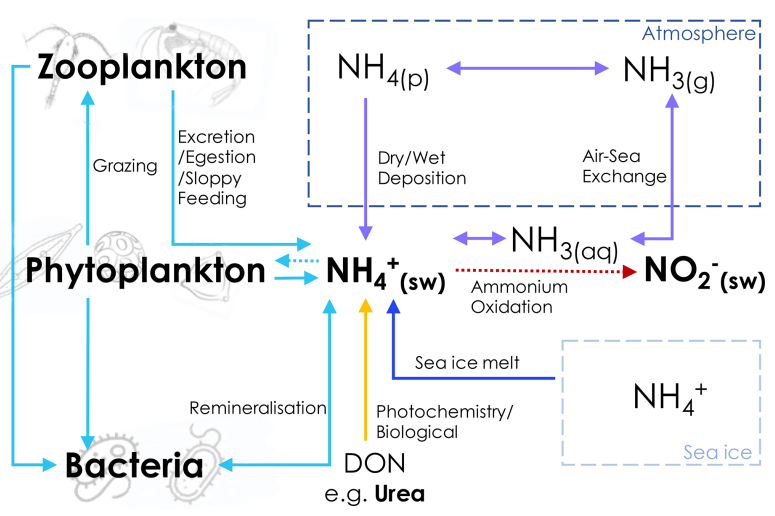

Figure 9. Schematic of the possible mixed-layer $\mathrm{NH}_{4}^{+}$assimilation and production pathways. Bold text indicates components of the $\mathrm{NH}_{4}^{+}$cycle that were directly measured in this study (seawater concentrations of $\mathrm{NH}_{4}^{+}, \mathrm{NO}_{2}^{-}$, and urea; phytoplankton, bacterial, and microzooplankton cell abundances), and dotted lines indicate processes for which we have direct rate measurements (phytoplankton uptake of $\mathrm{NH}_{4}^{+}$, oxidation of $\mathrm{NH}_{4}^{+}$to $\mathrm{NO}_{2}^{-}$). Dashed-line boxes represent the atmosphere and sea ice, with all other processes occurring in the ocean. DON - dissolved organic nitrogen; $\mathrm{NH}_{3(\mathrm{aq})}$ - aqueous (seawater) ammonia; $\mathrm{NH}_{4(\mathrm{p})}$ - ammonium aerosols (including ammonium sulfate, ammonium bisulfate, and ammonium nitrate); $\mathrm{NH}_{3(\mathrm{~g})}$ - ammonia gas.

\subsubsection{Ammonium removal}

Ammonium assimilation. Microbial growth is limited in the winter Southern Ocean (Arrigo et al., 2008; Smith et al., 2000; Takao et al., 2012), resulting in low cell abundances and nutrient uptake rates (Church et al., 2003; lida and Odate, 2014; Mdutyana et al., 2020). However, while the concentrations of chl $a$ and rates of NPP were low across our transect, they were not negligible (Figs. 3a and 5a), consistent with previous reports for this season (Mordy et al., 1995; Pomeroy and Wiebe, 2001). Southern Ocean phytoplankton are adapted to survive suboptimal conditions; for example, numerous species achieve their maximum growth rates at temperatures that are considerably lower than the optimal growth temperatures of temperate and tropical species (2$9^{\circ} \mathrm{C}$ versus $10-30$ and $15-35^{\circ} \mathrm{C}$, respectively), with sharp declines in growth rates observed at temperatures outside this range (Boyd et al., 2013; Coello-Camba and Agusti, 2017; Fiala and Oriol, 1990). In addition, ice-free Southern Ocean waters typically extend to $<60^{\circ} \mathrm{S}$ in the eastern Atlantic and western Indian sectors in winter, so even though irradiance levels may not be optimal for phytoplankton growth, there is always some light available for photosynthesis. The hostile wintertime conditions of the open Southern Ocean do not, therefore, prevent ecosystem functioning, although the microbial dynamics and associated biogeochemical processes 
differ from those occurring in summer (Smart et al., 2015; Mdutyana et al., 2020).

We measured fairly low surface $\mathrm{NH}_{4}^{+}$uptake rates (3.0$13.2 \mathrm{nMd}^{-1}$; Fig. 5b) compared to previous wintertime observations (ranging from 32-66 $\mathrm{nM} \mathrm{d}^{-1}$; Cota et al., 1992; Mdutyana et al., 2020; Philibert et al., 2015). Such low rates, if generally representative of winter, would limit mixed-layer $\mathrm{NH}_{4}^{+}$drawdown, especially south of the PF where $\rho \mathrm{NH}_{4}^{+}$ was particularly low. Recycled $\mathrm{N}\left(\mathrm{NH}_{4}^{+}+\right.$urea) nonetheless accounted for most of the $\mathrm{N}$ assimilated during winter, including in the AZ (Fig. 5b).

The available $\delta^{15} \mathrm{~N}-\mathrm{PON}$ data suggest that the preferential reliance of phytoplankton on recycled $\mathrm{N}$ may have persisted from the late summer. In theory, PON generated in early summer through mid-summer from the assimilation of upwelled $\mathrm{NO}_{3}^{-}\left(\delta^{15} \mathrm{~N}^{-N^{-}}{ }_{3}^{-}\right.$of $5.2 \%$ in the $\mathrm{AZ}$ and $6.2 \%$ in the SAZ; Smart et al., 2015; Fripiat et al., 2019, 2021) will have $\delta^{15} \mathrm{~N}$ of $\sim 0 \%$ in the $\mathrm{AZ}$ and $1 \%-2 \%$ in the SAZ given the isotope effect of $\mathrm{NO}_{3}^{-}$assimilation and the degree of seasonal $\mathrm{NO}_{3}^{-}$drawdown (Sigman et al., 1999; Granger et al., 2004, 2010). Such $\delta^{15}$ N-PON values have indeed been measured in the early-summer and mid-summer Southern Ocean (Lourey et al., 2003; Smart et al., 2020; Soares et al., 2015). By late summer, $\delta^{15} \mathrm{~N}$-PON has been observed to decline to between $-5 \%$ and $-1 \%$, with the lowest values occurring in the AZ (Lourey et al., 2003; Smart et al., 2020; Trull et al., 2008). Since the $\delta^{15} \mathrm{~N}$ of recycled $\mathrm{N}$ is expected to be low ( $<0 \%$; Checkley and Miller, 1989; Macko et al., 1986), the early-to-late-summer decline in $\delta^{15} \mathrm{~N}-\mathrm{PON}$ implicates a switch from dominantly $\mathrm{NO}_{3}^{-}$-supported to dominantly recycled $\mathrm{N}$-supported phytoplankton growth (Lourey et al., 2003). For the SAZ, the subsequent late-summer-towinter rise in $\delta^{15} \mathrm{~N}-\mathrm{PON}$ (i.e. from ca. $-1 \%$ to $1 \%$ - $2.5 \%$; Fig. 4) has previously been attributed to PON decomposition by heterotrophic bacteria (Smart et al., 2020), during which ${ }^{14} \mathrm{~N}-\mathrm{NH}_{4}^{+}$is preferentially remineralised, leaving the remaining PON enriched in ${ }^{15} \mathrm{~N}$ (Möbius, 2013). That $\mathrm{NH}_{4}^{+}$concentrations are not elevated in the $\mathrm{SAZ}$ mixed layer in winter (Fig. 2b) indicates that the remineralised $\mathrm{NH}_{4}^{+}$is rapidly re-assimilated by phytoplankton and/or oxidised to $\mathrm{NO}_{2}^{-}$in this zone. In the AZ, the much lower $\delta^{15} \mathrm{~N}-\mathrm{PON}$ of $-3 \%$ o to $-1 \%$ o that we observe in winter surface waters requires the sustained assimilation of low- $\delta^{15} \mathrm{~N} \mathrm{~N}$ (i.e. recycled $\mathrm{N}$ ) to offset a remineralisation-driven $\delta^{15} \mathrm{~N}$ rise akin to that of the SAZ. We conclude that Southern Ocean phytoplankton preferentially consume regenerated $\mathrm{N}$ from late summer until at least July (albeit at low rates in winter), particularly south of the PF.

The fact that $\mathrm{NH}_{4}^{+}$accumulated in the winter mixed layer despite being the preferred phytoplankton $\mathrm{N}$ source in late summer through winter implies that low rates of $\mathrm{NH}_{4}^{+}$uptake contributed to its accumulation. Multiple factors may cause low rates of photoautotrophic $\mathrm{NH}_{4}^{+}$assimilation, including depleted $\mathrm{NH}_{4}^{+}$and micronutrient concentrations, light limitation, and low temperatures. North of the $\mathrm{SAF}, \mathrm{NH}_{4}^{+}$concen- trations below detection likely limited $\rho \mathrm{NH}_{4}^{+}$, as evidenced by the fact that in a series of experiments conducted on the same cruise, $\rho \mathrm{NH}_{4}^{+}$increased with the addition of $\mathrm{NH}_{4}^{+}$at these stations (Mdutyana, 2021). By contrast, south of the $\mathrm{SAF}, \mathrm{NH}_{4}^{+}$concentrations were similar to or higher than the half-saturation constant $\left(K_{\mathrm{m}}\right)$ derived for $\mathrm{NH}_{4}^{+}$uptake in the winter Southern Ocean (0.2 to $0.4 \mu \mathrm{M}$; Mdutyana, 2021), suggesting that something other than $\mathrm{NH}_{4}^{+}$availability was limiting to phytoplankton at these latitudes.

Iron is not directly involved in $\mathrm{NH}_{4}^{+}$assimilation but is required for electron transport during photosynthesis and respiration, as well as for chlorophyll synthesis (Raven, 1988). While iron limitation is widespread across the Southern Ocean (Janssen et al., 2020; Pausch et al., 2019; Viljoen et al., 2019), iron availability appears to be higher in winter than during other seasons (Mtshali et al., 2019; Tagliabue et al., 2014) due to enhanced mixing, storms, and increased aeolian deposition (Coale et al., 2005; Honjo et al., 2000; Sedwick et al., 2008). The fact that $\rho \mathrm{NO}_{3}^{-}$and $\rho \mathrm{NH}_{4}^{+}$were generally similar across the transect (Fig. 5b) argues against a dominant role for iron in controlling $\rho \mathrm{NH}_{4}^{+}$since $\mathrm{NO}_{3}^{-}$consumption has a far higher iron requirement than $\mathrm{NH}_{4}^{+}$assimilation (Morel et al., 1991).

In contrast to $\mathrm{NH}_{4}^{+}$and iron availability, light limitation is exacerbated in winter due to low insolation, increased cloud cover, and mixed layers that can be hundreds of metres deeper than the euphotic zone (Buongiorno Nardelli et al., 2017; Sallée et al., 2010). Light is thus often considered the dominant constraint on Southern Ocean primary productivity in this season (Thomalla et al., 2011; Llort et al., 2019; Wadley et al., 2014). However, since $\mathrm{NH}_{4}^{+}$assimilation by phytoplankton is fairly energetically inexpensive (Dortch, 1990), it should occur even under low-light conditions (recognising that light remains critical for coincident $\mathrm{CO}_{2}$ fixation). Heterotrophic bacteria can also consume $\mathrm{NH}_{4}^{+}$(Kirchman, 1994), including in the dark, as they derive energy from organic carbon oxidation rather than light. At an ecosystem level, therefore, $\mathrm{NH}_{4}^{+}$assimilation may not be primarily limited by light, although this parameter clearly strongly controls the rate and distribution of NPP (Fig. 5a).

Previous observations suggest that temperature can influence $\mathrm{NH}_{4}^{+}$uptake, especially in winter (Glibert, 1982; Reay et al., 2001). The negative effect of temperature appears to be enhanced under high-nutrient and low-light conditions, at least in the case of phytoplankton growth rates (Baird et al., 2001). Experiments conducted coincidentally with our sampling showed that the maximum rate of $\mathrm{NH}_{4}^{+}$uptake $\left(V_{\max }\right)$ achievable by the in situ community was strongly negatively correlated with temperature and latitude (Mdutyana, 2021), with the latter parameter representing the combined role of light, temperature, and possibly iron, the average concentration of which appears to increase from the SAZ to the AZ (Tagliabue et al., 2012). We conclude that these three drivers, along with $\mathrm{NH}_{4}^{+}$availability north of the SAF, may all play a role in controlling photoautotrophic $\mathrm{NH}_{4}^{+}$assimilation in 
the winter Southern Ocean, with complex interactions among them that are difficult to disentangle.

In addition to physical and chemical limitations, microbial preference for other $\mathrm{N}$ species may impact $\mathrm{NH}_{4}^{+}$depletion. For example, the preferential uptake of urea and/or other dissolved organic N (DON) species by some organisms (e.g. picoeukaryotes, cyano- or heterotrophic bacteria) could cause a net decrease in the total $\mathrm{NH}_{4}^{+}$uptake rates. While urea has been shown to constitute a large fraction of the total $\mathrm{N}$ assimilated by Southern Ocean phytoplankton in summer and autumn (albeit mainly in the SAZ; Joubert et al., 2011; Thomalla et al., 2011), we measured fairly low $\rho$ Urea (Fig. 5b), which is perhaps unsurprising given the low ambient urea concentrations (Table 1). The exceptions were stations 37.0 and $43.0^{\circ} \mathrm{S}$ where $\rho$ Urea was higher than $\rho \mathrm{NH}_{4}^{+}$, coincident with very low ambient $\mathrm{NH}_{4}^{+}(0.10 \mu \mathrm{M}$ and below detection, respectively) and relatively high urea concentrations $(0.36$ and $0.15 \mu \mathrm{M}$, respectively).

Community composition can also alter the $\mathrm{N}$ uptake regime. Small phytoplankton, such as the numerically dominant nano- and picoeukaryotes, are more likely to consume $\mathrm{NH}_{4}^{+}$and urea than $\mathrm{NO}_{3}^{-}$(Koike et al., 1986; Lee et al., 2012, 2013), especially under conditions of iron and light limitation (Sunda and Huntsman, 1997). Across our transect, reduced $\mathrm{N}$ (i.e. $\mathrm{NH}_{4}^{+}+$urea) uptake exceeded $\mathrm{NO}_{3}^{-}$ uptake for both the total phytoplankton community (transect average of $12.0 \pm 0.9 \mathrm{nM} \mathrm{d}^{-1}$ for reduced $\mathrm{N}$ versus $5.8 \pm 1.0 \mathrm{nM} \mathrm{d}^{-1}$ for $\mathrm{NO}_{3}^{-}, f$ ratio of 0.36$)$ and the pico size fraction $\left(5.0 \pm 1.2 \mathrm{nM} \mathrm{d}^{-1}\right.$ versus $1.9 \pm 1.2 \mathrm{nMd}^{-1}, f$ ratio of 0.27 ; Fig. 5b). That said, the $\mathrm{NO}_{3}^{-}$uptake rates were not negligible, including in the pico size fraction. In the PFZ and $\mathrm{AZ}, \mathrm{NO}_{3}^{-}$uptake by the picoplankton was far more strongly correlated with the abundance of picoeukaryotes than Synechococcus ( $r=0.75$ and $r=0.03$, respectively), consistent with observations of dominant reliance on $\mathrm{NO}_{3}^{-}$by picoeukaryotes and $\mathrm{NH}_{4}^{+}$by Synechococcus in other ocean regions (Fawcett et al., 2011, 2014; Painter et al., 2014). Additionally, Synechococcus abundance was strongly correlated with $\mathrm{NH}_{4}^{+}$concentration south of the SAF ( $\left.r=0.65\right)$. In the nano+ size class, $\mathrm{NO}_{3}^{-}$uptake was likely driven in the SAZ by dinoflagellates and nanoeukaryotes and in the PFZ and AZ by diatoms, which remain active in these zones in winter (Weir et al., 2020). By contrast, nanoeukaryotes, which have a higher per-cell nutrient requirement than the equally abundant picoeukaryotes, may have dominated $\mathrm{NH}_{4}^{+}$uptake in the PFZ and AZ given that higher nanoeukaryote abundances corresponded with lower $\mathrm{NH}_{4}^{+}$concentrations at a number of stations (e.g. stations 50.0, 51.1, and 55.5 ${ }^{\circ}$ S; Fig. 6b).

The low abundances of diatoms and dinoflagellates and absence of coccolithophores across our transect (Fig. 6a) are expected given the limitations imposed on nutrient uptake and $\mathrm{CO}_{2}$ fixation by winter Southern Ocean conditions. The lower surface-area-to-volume ratio of large cells means that they rapidly experience diffusion limitation of $\mathrm{NH}_{4}^{+}$and micronutrient uptake and are more susceptible to light limita- tion (Finkel et al., 2004), resulting in their being outcompeted by smaller species for essential resources (Franck et al., 2005; Cavender-Bares et al., 1999). The near absence of centric diatoms is also best explained thus, particularly given their low surface-area-to-volume ratio compared to the more abundant pennate species (Kobayashi and Takahashi, 2002) that are more likely to consume $\mathrm{NH}_{4}^{+}$(Semeneh et al., 1998). Diatom success in winter may also be limited by enhanced mixing, as this group generally prefers stratified waters (Kopczyńska et al., 2007).

In sum, $\mathrm{NH}_{4}^{+}$uptake rates were low across our transect but not negligible, indicating that phytoplankton activity in winter, which is dominated by smaller species, is a sink for $\mathrm{NH}_{4}^{+}$. The hostile conditions of the winter Southern Ocean imposed limitations on $\mathrm{NH}_{4}^{+}$uptake that varied with latitude, with $\mathrm{NH}_{4}^{+}$concentrations controlling $\rho \mathrm{NH}_{4}^{+}$north of the SAF, while light and temperature were important south of the SAF. Additionally, Synechococcus, nanoeukaryotes, and pennate diatoms likely dominated $\mathrm{NH}_{4}^{+}$assimilation, consistent with previous observations from the Southern Ocean and elsewhere (Klawonn et al., 2019; Semeneh et al., 1998).

Ammonium oxidation. Nitrification removes more mixedlayer $\mathrm{NH}_{4}^{+}$in winter than phytoplankton assimilation south of the $\mathrm{PF}$, with $\mathrm{NH}_{4}^{+}$oxidation rates that were 2 to 5 times the co-occurring $\mathrm{NH}_{4}^{+}$uptake rates (Fig. 5c). The comparative success of ammonia oxidisers may be due to decreased competition with phytoplankton for $\mathrm{NH}_{4}^{+}$, augmented by decreased photoinhibition (Wan et al., 2018; Lu et al., 2020), elevated $\mathrm{NH}_{4}^{+}$availability (Baer et al., 2014; Mdutyana et al., 2020; Mdutyana, 2021), and the apparently minor effect of temperature on $\mathrm{NH}_{4}^{+}$oxidation (Bianchi et al., 1997; Baer et al., 2014; Horak et al., 2013; Mdutyana, 2021). One implication of the dominance of $\mathrm{NH}_{4}^{+}$oxidation in winter is that in addition to the limitations on photoautotrophic $\mathrm{NH}_{4}^{+}$assimilation discussed above, low phytoplankton success in the AZ may result from nitrifiers outcompeting phytoplankton for scarce resources (e.g. trace elements required for enzyme functioning, such as iron and copper; Amin et al., 2013; Maldonado et al., 2006; Shafiee et al., 2019) under conditions of low incident light and enhanced mixing.

The $K_{\mathrm{m}}$ derived for $\mathrm{NH}_{4}^{+}$oxidation in the winter Southern Ocean has recently been reported to be low $(0.03$ to $0.14 \mu \mathrm{M})$, with ammonia oxidisers observed to become saturated at ambient $\mathrm{NH}_{4}^{+}$concentrations of $\sim 0.1-0.2 \mu \mathrm{M}$ (Mdutyana, 2021). This means that south of the SAF in winter 2017, ammonia oxidisers were not substrate limited (as implied by the lack of correlation between $\mathrm{NH}_{4}^{+}$ox and $\mathrm{NH}_{4}^{+}$concentration; Table S1), which raises the question of why $\mathrm{NH}_{4}^{+}$oxidation did not occur at higher rates. The answer may indirectly involve temperature, in that psychrophilic organisms can be less responsive to high substrate concentrations at low temperatures (Baer et al., 2014). Another possibility is that $\mathrm{NH}_{4}^{+}$ oxidation was iron-limited (Shiozaki et al., 2016; Shafiee et al., 2019; Mdutyana, 2021). In any case, ammonia oxidisers were moderately successful across the surface Southern 
Ocean in winter, with low light, reduced competition with phytoplankton, and substrate repletion likely explaining the elevated $\mathrm{NH}_{4}^{+}$oxidation rates south of the $\mathrm{PF}$ compared to the stations to the north.

\subsubsection{Ammonium production and other sources of ammonium}

$\mathrm{NH}_{4}^{+}$production must have been sustained during the winter to maintain a mixed-layer $\mathrm{NH}_{4}^{+}$pool south of the SAF that was high in concentration relative to the early summer. Indeed, the residence time estimated for $\mathrm{NH}_{4}^{+}$in winter $(10$ to $38 \mathrm{~d}$ ) is considerably shorter than the transition from late summer to winter (approximately 3 months), indicating that heterotrophic $\mathrm{NH}_{4}^{+}$production, which would have occurred coincidentally with $\mathrm{NH}_{4}^{+}$consumption, must have been ongoing in winter. We estimate the rate of this wintertime $\mathrm{NH}_{4}^{+}$ production to be $23.4 \pm 6.6 \mathrm{nMd}^{-1}$.

Heterotrophic activity by bacteria. Heterotrophic bacteria contribute significantly to $\mathrm{NH}_{4}^{+}$production in the Southern Ocean (Hewes et al., 1985; Koike et al., 1986; Tréguer and Jacques, 1992), including in winter (Rembauville et al., 2017). In our dataset, lower ratios of photosynthetic to heterotrophic cells were observed at stations with higher $\mathrm{NH}_{4}^{+}$ concentrations (e.g. stations 48.9, 53.0, 54.0, and $57.8^{\circ} \mathrm{S}$; Fig. S5a), consistent with a role for the heterotrophic bacteria present at the time of sampling in generating the ambient $\mathrm{NH}_{4}^{+}$pool. The potential for ongoing heterotrophic activity can also be inferred from the high detrital particle counts along the transect (Fig. 7). However, since heterotrophic bacteria are likely more active in late summer and autumn when the temperature and the supply of labile PON are higher (Becquevort et al., 2000; Dennett et al., 2001; Pomeroy and Wiebe, 2001; Smart et al., 2020), we expect that the winter $\mathrm{NH}_{4}^{+}$pool includes $\mathrm{NH}_{4}^{+}$produced in late summer and autumn. A further consideration is assimilation of $\mathrm{NH}_{4}^{+}$by heterotrophic bacteria, reported to occur at elevated rates in the Southern Ocean mixed layer in winter (Mdutyana et al., 2020; Sect. S3). If this process is a persistent feature of the winter Southern Ocean, it will decrease the net contribution of heterotrophic bacteria to $\mathrm{NH}_{4}^{+}$accumulation. We conclude that it is unlikely that the surface $\mathrm{NH}_{4}^{+}$pool measured in winter derived solely from wintertime bacterial $\mathrm{NH}_{4}^{+}$ production given that yet higher $\mathrm{NH}_{4}^{+}$concentrations have been observed in late summer and autumn (Becquevort et al., 2000; Dennett et al., 2001), including in the present study (see Sect. 4.2 below).

Heterotrophic activity by zooplankton. While the microzooplankton enumerated in this study occurred at very low abundances, those that were present likely contributed to the $\mathrm{NH}_{4}^{+}$flux. For example, at stations 48.9 and $54.0^{\circ} \mathrm{S}$ in the PFZ and AZ, respectively, both the ratios of photosynthetic to heterotrophic cells and the absolute abundances of heterotrophic bacteria were low, while the microzooplankton abundances and $\mathrm{NH}_{4}^{+}$concentrations were elevated com- pared to at nearby stations. The implication of these observations is that elevated microzooplankton abundances may help to explain high $\mathrm{NH}_{4}^{+}$concentrations in waters with low numbers of heterotrophic bacteria, although we note that this scenario occurred only at two stations. On balance, we posit that microzooplankton are less important for wintertime $\mathrm{NH}_{4}^{+}$ production than heterotrophic bacteria given their low abundances in the surface layer (Fig. 6a; Atkinson et al., 2012). That said, it is possible that the contribution of microzooplankton (and/or macrozooplankton) to the $\mathrm{NH}_{4}^{+}$pool surpasses that of heterotrophic bacteria under certain conditions (Koike et al., 1986; Priddle et al., 1998), such as in (late) summer and near regions of frontal upwelling in response to elevated rates of phytoplankton biomass accumulation.

Above, we have assumed that $\mathrm{NH}_{4}^{+}$production is the direct result of heterotrophy. However, there are other possible mechanisms of $\mathrm{NH}_{4}^{+}$supply that should be considered. We briefly address some of these processes below, noting that for most, there are very few to no observations available from the Southern Ocean.

DON cycling. $\mathrm{NH}_{4}^{+}$can be released by heterotrophic bacteria that directly consume DON (e.g. urea; Billen, 1983; Tupas and Koike, 1990) and possibly also by ammonia oxidisers that convert DON to $\mathrm{NH}_{4}^{+}$intracellularly, through the equilibration of the intra- and extracellular $\mathrm{NH}_{4}^{+}$pools (Kitzinger et al., 2019). DON can also be converted to $\mathrm{NH}_{4}^{+}$ through photodegradation by UV radiation (e.g. Aarnos et al., 2012). Bacterial decomposition of DON (rather than $\mathrm{PON}$ ) to $\mathrm{NH}_{4}^{+}$is implicit in most estimates of ammonification, however, and cellular $\mathrm{NH}_{4}^{+}$efflux by ammonia oxidisers is likely extremely low given that they require $\mathrm{NH}_{4}^{+}$to fix $\mathrm{CO}_{2}$. Additionally, the low light flux to the surface of the Southern Ocean in winter means that photodegradation will not yield a significant supply of $\mathrm{NH}_{4}^{+}$. Thus, DON conversion to $\mathrm{NH}_{4}^{+}$, through any mechanism, is probably negligible.

External inputs of ammonium. High surface ocean $\mathrm{NH}_{4}^{+}$ concentrations may theoretically derive from external inputs of $\mathrm{NH}_{4}^{+}$, such as $\mathrm{N}_{2}$ fixation, $\mathrm{NH}_{4}^{+}$aerosol deposition, or sea-ice melt. $\mathrm{N}_{2}$ fixation should be below detection in the winter Southern Ocean due to the cold temperatures, lowlight and low-iron conditions, and high $\mathrm{NO}_{3}^{-}$concentrations (Jiang et al., 2018; Knapp et al., 2012; Kustka et al., 2003). $\mathrm{NH}_{4}^{+}$aerosols are unlikely to be abundant over regions of the Southern Ocean remote from islands and coastal Antarctica, particularly in winter when $\mathrm{NH}_{4}^{+}$aerosol concentrations have been shown to reach a minimum (Legrand et al., 1998; Xu et al., 2019). Moreover, the aerosols that are present over the open Southern Ocean will derive mainly from surface ocean $\mathrm{NH}_{3}$ efflux; once re-deposited, this $\mathrm{NH}_{4}^{+}$does not constitute a new input to surface waters (Altieri et al., 2021). Finally, since our sampling took place before the sea ice reached its northernmost extent (Cavalieri and Parkinson, 2008), the dominant process would have been sea-ice formation rather than sea-ice melt, the latter an occasional source of $\mathrm{NH}_{4}^{+}$ (Kattner et al., 2004; Zhou et al., 2014). In any case, we ob- 
served elevated $\mathrm{NH}_{4}^{+}$concentrations as far north as $46^{\circ} \mathrm{S}$, $\sim 1700 \mathrm{~km}$ beyond the influence of sea-ice melt.

\subsection{Seasonal cycling of $\mathrm{NH}_{4}^{+}$in the Southern Ocean mixed layer south of the SAF}

The $\mathrm{NH}_{4}^{+}$concentration data collected over the 2018/19 annual cycle provide context for interpreting our winter 2017 dataset, allowing us to address our hypothesis that $\mathrm{NH}_{4}^{+}$production in late summer and autumn contributes to the elevated $\mathrm{NH}_{4}^{+}$concentrations measured in winter.

The very low $\mathrm{NH}_{4}^{+}$concentrations observed in early summer (Fig. 8a) are consistent with high rates of phytoplankton $\mathrm{NH}_{4}^{+}$assimilation during the spring and early-summer growing period (Mdutyana et al., 2020; Savoye et al., 2004; Daly et al., 2001). By late summer, the $\mathrm{NH}_{4}^{+}$concentrations increased (Fig. 8b) presumably due to elevated heterotrophic activity (i.e. bacterial decomposition and zooplankton grazing) following the accumulation of algal biomass (Mengesha et al., 1998; Le Moigne et al., 2013), coupled with iron limitation and/or silicate limitation of phytoplankton (Hiscock et al., 2003; Sosik and Olson, 2002) and enhanced grazing pressure (Becquevort et al., 2000). Mixed-layer $\mathrm{NH}_{4}^{+}$remained high between late summer and winter (Fig. 8b-c), likely due to sustained heterotrophic $\mathrm{NH}_{4}^{+}$production in excess of $\mathrm{NH}_{4}^{+}$removal. This notion is supported by estimates of the residence time of $\mathrm{NH}_{4}^{+}$. We calculate that in summer, the in situ $\mathrm{NH}_{4}^{+}$pool would be depleted in 2 to $27 \mathrm{~d}$ (median of $5 \mathrm{~d}$ ) without coincident $\mathrm{NH}_{4}^{+}$production. In addition, the net decline in $\mathrm{NH}_{4}^{+}$concentration of $0.31 \pm 0.97 \mu \mathrm{M}$ between late summer and winter requires an average $\mathrm{NH}_{4}^{+}$production rate of $52.8 \pm 25.0 \mathrm{nM} \mathrm{d}^{-1}$ given the observed $\mathrm{NH}_{4}^{+}$assimilation rates. This estimate is remarkably similar to the only measurements of $\mathrm{NH}_{4}^{+}$regeneration available for the Southern Ocean, measured near the Antarctic Peninsula in summer (average of $55 \mathrm{nM} \mathrm{d}^{-1}$; Goeyens et al., 1991).

By early spring, the $\mathrm{NH}_{4}^{+}$concentrations had declined (Fig. 8d), implicating increased photosynthetic activity, and thus nutrient assimilation, following the alleviation of light limitation. We suggest that any $\mathrm{NH}_{4}^{+}$remaining in late winter would have been consumed in early spring prior to significant $\mathrm{NO}_{3}^{-}$drawdown because far less energy (i.e. light) is required for its assimilation (Dortch, 1990). The high $\mathrm{NH}_{4}^{+}$concentrations subsequently observed in late spring (mainly in the PFZ; Fig. 8e) can be explained by elevated heterotrophic activity in response to high levels of regional phytoplankton growth driven by the frontal upwelling of limiting nutrients (Becquevort et al., 2000; Mayzaud et al., 2002).

From our six transects of surface $\mathrm{NH}_{4}^{+}$concentrations across the Southern Ocean, we propose a seasonal cycle for mixed-layer $\mathrm{NH}_{4}^{+}$south of the SAF (Fig. 8f). Our proposal is consistent with previous characterisations of the earlysummer-to-autumn evolution of Southern Ocean $\mathrm{NH}_{4}^{+}$concentrations (i.e. from below detection due to phytoplankton assimilation to elevated due to net heterotrophy). How- ever, it contradicts the hypothesis that $\mathrm{NH}_{4}^{+}$will subsequently decline due to persistent but low rates of photosynthesis that yield insufficient biomass to support elevated heterotrophy in autumn, thus driving a coincident decrease in photosynthetic and heterotrophic activity (Koike et al., 1986; Serebrennikova and Fanning, 2004). Instead, our data evince a gradual decline in mixed-layer $\mathrm{NH}_{4}^{+}$concentrations from late summer through winter. This decline can be explained by heterotrophic $\mathrm{NH}_{4}^{+}$production outpacing $\mathrm{NH}_{4}^{+}$ removal in late summer and/or autumn, with $\mathrm{NH}_{4}^{+}$regeneration then decreasing during winter to lower rates than the combined rate of $\mathrm{NH}_{4}^{+}$assimilation and oxidation. By late spring, $\mathrm{NH}_{4}^{+}$reaches concentrations similar to those observed in early summer as the improved growing conditions (i.e. elevated light and iron availability; Ellwood et al., 2008; Mtshali et al., 2019) allow phytoplankton to rapidly consume any $\mathrm{NH}_{4}^{+}$remaining at the end of winter and subsequently produced in spring. An exception to this scenario is elevated, localised $\mathrm{NH}_{4}^{+}$production near fronts, such as we observed in late spring 2019, which likely resulted from biological activity supported by frontal upwelling of silicateand iron-bearing Upper Circumpolar Deep Water (Prézelin et al., 2000).

\section{Summary and implications}

Our study of the upper Southern Ocean, focused on the infrequently sampled winter season, provides new insights into the internal cycling of $\mathrm{N}$ in the mixed layer of a globally important region. We attribute the elevated $\mathrm{NH}_{4}^{+}$concentrations that persist in the winter mixed layer south of the SAF to sustained heterotrophic $\mathrm{NH}_{4}^{+}$production in excess of $\mathrm{NH}_{4}^{+}$ removal, driven by the temperature, light, and possibly iron limitation of phytoplankton and nitrifiers. We further suggest that heterotrophic bacteria are the main $\mathrm{NH}_{4}^{+}$producers in winter and that the contribution of external sources to the Southern Ocean's mixed-layer $\mathrm{NH}_{4}^{+}$pool is negligible. From observations of surface $\mathrm{NH}_{4}^{+}$concentrations made between December 2018 and November 2019, we deduce that the elevated mixed-layer $\mathrm{NH}_{4}^{+}$concentrations measured in winter cannot be due solely to wintertime $\mathrm{NH}_{4}^{+}$production. Instead, we propose that $\mathrm{NH}_{4}^{+}$accumulates to its highest concentrations in late summer following the peak phytoplankton growing season, after which sustained heterotrophy throughout the autumn and winter prevents this $\mathrm{NH}_{4}^{+}$from being fully depleted until the early spring, even though the rate of $\mathrm{NH}_{4}^{+}$ removal must exceed that of $\mathrm{NH}_{4}^{+}$production over this period. Measurements of heterotrophic $\mathrm{NH}_{4}^{+}$production rates are required to confirm the hypothesised seasonal cycle of $\mathrm{NH}_{4}^{+}$in the Southern Ocean mixed layer, and higher-spatialresolution sampling of plankton community composition and $\mathrm{N}$ removal rates may help to explain local variability in $\mathrm{NH}_{4}^{+}$ concentrations, particularly near the fronts. 
In net, the Southern Ocean mixed layer is a biological source of $\mathrm{CO}_{2}$ to the atmosphere in autumn and winter (Mongwe et al., 2018). The persistence of elevated $\mathrm{NH}_{4}^{+}$ concentrations across the polar Southern Ocean between late summer and winter implies that this biological $\mathrm{CO}_{2}$ production occurs not only because $\mathrm{NO}_{3}^{-}$drawdown is weak relative to $\mathrm{NO}_{3}^{-}$supply at this time (e.g. Gibson and Trull, 1999; Gray et al., 2018; Hauck et al., 2015; Mongwe et al., 2018; Shadwick et al., 2015) but also because the ambient conditions allow for $\mathrm{NH}_{4}^{+}$accumulation. There are additional implications of our observations. For example, $\mathrm{NH}_{4}^{+}$concentrations $>1 \mu \mathrm{M}$ (and at times $>0.5 \mu \mathrm{M}$ ) have been reported to inhibit $\mathrm{NO}_{3}^{-}$assimilation, including in the Southern Ocean (Cochlan, 1986; Goeyens et al., 1995; Philibert et al., 2015; Reay et al., 2001). Inhibition of $\mathrm{NO}_{3}^{-}$assimilation due to the seasonal accumulation of $\mathrm{NH}_{4}^{+}$would constitute an inefficiency in the biological pump. However, we observed little evidence of this effect in winter 2017 - the southward decrease in $\rho \mathrm{NO}_{3}^{-}$was not stronger than that of $\rho \mathrm{NH}_{4}^{+}$despite the latitudinal increase in $\mathrm{NH}_{4}^{+}$concentration, and we observed no relationship between $\mathrm{NH}_{4}^{+}$concentration and the proportion of $\mathrm{NO}_{3}^{-}$to $\mathrm{NO}_{3}^{-}+\mathrm{NH}_{4}^{+}$uptake (i.e. the $f$ ratio; Table S1).

The implications of $\mathrm{NH}_{4}^{+}$cycling extend beyond the upper ocean to the atmosphere, since ammonium aerosols that influence Earth's albedo (Tevlin and Murphy, 2019) are formed in the marine boundary layer from reactions of $\mathrm{NH}_{3}$ gas with acidic species. In the remote Southern Ocean, marine $\mathrm{NH}_{3}$ emissions, which are the largest natural contributors to $\mathrm{NH}_{3}$ globally, are likely the dominant local source of $\mathrm{NH}_{3}$ to the atmosphere (Paulot et al., 2015). Surface ocean $\mathrm{NH}_{4}^{+}$concentrations play a central role in determining the sign and magnitude of the air-sea $\mathrm{NH}_{3}$ flux, along with wind speed, surface ocean temperature, and $\mathrm{pH}$. Therefore, the biogeochemical pathways that underpin seasonal changes in surface ocean $\mathrm{NH}_{4}^{+}$concentrations represent an important control on the remote Southern Ocean air-sea $\mathrm{NH}_{3}$ flux, with consequences for aerosol composition, cloud formation, and climate (Altieri et al., 2021).

Data availability. All data used in this paper can be found at https://doi.org/10.5281/zenodo.3884606. (Smith, 2020)

Supplement. The supplement related to this article is available online at: https://doi.org/10.5194/bg-19-715-2022-supplement.

Author contributions. SS, KEA, DRW, and SEF planned the campaign; SS, MM, SG, KAMS, and JMB collected the samples and conducted the experiments; SS, MM, RGP, SG, and KAMS made the measurements; SS, KEA, MM, RGP, DW, and SEF analysed the data; SS and SEF wrote the manuscript draft, with substantial input from KEA; all authors reviewed, edited, and approved the manuscript.

Competing interests. The contact author has declared that neither they nor their co-authors have any competing interests.

Disclaimer. Publisher's note: Copernicus Publications remains neutral with regard to jurisdictional claims in published maps and institutional affiliations.

Special issue statement. This article is part of the special issue "The Weddell Sea and the ocean off Dronning Maud Land: unique oceanographic conditions shape circumpolar and global processes - a multi-disciplinary study (OS/BG/TC inter-journal SI)". It is not associated with a conference.

Acknowledgements. We are grateful to Captain Knowledge Bengu and the crew of the R/V SA Agulhas II and chief scientists Hermann Luyt, Marcello Vichi, and Thomas Ryan-Keogh. We thank Tahlia Henry for CTD operations and CTD and thermosalinograph data processing. We are grateful to the students from the Cape Peninsula University of Technology for help with sample collection and analysis of chl $a$, and we thank Raquel Flynn, Mishka Rawatlal, and Raymond Roman for assistance with nutrient analyses. We acknowledge the Flow Cytometry Core Facility at the University of Cape Town (UCT) and the efforts of Ian Newton at the Stable Light Isotope Laboratory (UCT).

Financial support. This research has been supported by the National Research Foundation (grant nos. 110732, 105539, 110735, 129232, 118615, 111716, 115335, 120105, 112380, 113193, and 108757); the University of Cape Town (Vice-Chancellor's Scholarship, Harry Crossley Foundation Research Fellowship, ViceChancellor Future Leaders 2030 programme, University Research Council Launching Grant, and University Equipment Committee grant); the African Academy of Sciences and Royal Society (FLAIR fellowship); the Department of Science and Innovation, South Africa (Biogeochemistry Research Infrastructure Platform); and the Department of Forestry, Fisheries, and the Environment, South Africa.

Review statement. This paper was edited by Carol Robinson and reviewed by three anonymous referees.

\section{References}

Aarnos, H., Ylöstalo, P., and Vähätalo, A. V.: Seasonal phototransformation of dissolved organic matter to ammonium, dissolved inorganic carbon, and labile substrates supporting bacterial biomass across the Baltic Sea, J. Geophys. Res.-Biogeo., 117, https://doi.org/10.1029/2010JG001633, 2012. 
Altabet, M. A.: Variations in nitrogen isotopic composition between sinking and suspended particles: Implications for nitrogen cycling and particle transformation in the open ocean, Deep-Sea Res., 35, 535-554, https://doi.org/10.1016/01980149(88)90130-6, 1988

Altieri, K. E., Spence, K. A. M., and Smith, S.: Air-Sea Ammonia Fluxes Calculated from High-Resolution Summertime Observations Across the Atlantic Southern Ocean, Geophys. Res. Lett., https://doi.org/10.1029/2020GL091963, 2021.

Amin, S. A., Moffett, J. W., Martens-Habbena, W., Jacquot, J. E., Han, Y., Devol, A., Ingalls, A. E., Stahl, D. A., and Armbrust, E. V.: Copper requirements of the ammonia-oxidizing archaeon $\mathrm{Ni}$ trosopumilus maritimus SCM1 and implications for nitrification in the marine environment, Limnol. Oceanogr., 58, 2037-2045, https://doi.org/10.4319/lo.2013.58.6.2037, 2013.

Armstrong, R. A.: An optimization-based model of ironlight-ammonium colimitation of nitrate uptake and phytoplankton growth, Limnol. Oceanogr., 44, 1436-1446, https://doi.org/10.4319/lo.1999.44.6.1436, 1999.

Arrigo, K. R., Dijken, G. L., and Bushinsky, S.: Primary production in the Southern Ocean, 1997-2006, J. Geophys. Res., 113, C08004, https://doi.org/10.1029/2007JC004551, 2008.

Atkinson, A., Ward, P., Hunt, B. P. V., Pakhomov, E. A., and Hosie, G. W.: An overview of Southern Ocean zooplankton data: abundance, biomass, feeding and functional relationships, CCAMLR Science, 19, 171-218, 2012.

Baer, S. E., Connelly, T. L., Sipler, R. E., Yager, P. L., and Bronk, D. A.: Effect of temperature on rates of ammonium uptake and nitrification in the western coastal Arctic during winter, Global Biogeochem. Cy., 28, 1455-1466, https://doi.org/10.1002/2013GB004765, 2014.

Baird, M. E., Emsley, S. M., and Mcglade, J. M.: Modelling the interacting effects of nutrient uptake, light capture and temperature on phytoplankton growth, J. Plankton Res., 23, 829-840, https://doi.org/10.1093/plankt/23.8.829, 2001.

Bakker, D. C. E., Pfeil, B., Landa, C. S., Metzl, N., O’Brien, K. M., Olsen, A., Smith, K., Cosca, C., Harasawa, S., Jones, S. D., Nakaoka, S., Nojiri, Y., Schuster, U., Steinhoff, T., Sweeney, C., Takahashi, T., Tilbrook, B., Wada, C., Wanninkhof, R., Alin, S. R., Balestrini, C. F., Barbero, L., Bates, N. R., Bianchi, A. A., Bonou, F., Boutin, J., Bozec, Y., Burger, E. F., Cai, W.-J., Castle, R. D., Chen, L., Chierici, M., Currie, K., Evans, W., Featherstone, C., Feely, R. A., Fransson, A., Goyet, C., Greenwood, N., Gregor, L., Hankin, S., Hardman-Mountford, N. J., Harlay, J., Hauck, J., Hoppema, M., Humphreys, M. P., Hunt, C. W., Huss, B., Ibánhez, J. S. P., Johannessen, T., Keeling, R., Kitidis, V., Körtzinger, A., Kozyr, A., Krasakopoulou, E., Kuwata, A., Landschützer, P., Lauvset, S. K., Lefèvre, N., Lo Monaco, C., Manke, A., Mathis, J. T., Merlivat, L., Millero, F. J., Monteiro, P. M. S., Munro, D. R., Murata, A., Newberger, T., Omar, A. M., Ono, T., Paterson, K., Pearce, D., Pierrot, D., Robbins, L. L., Saito, S., Salisbury, J., Schlitzer, R., Schneider, B., Schweitzer, R., Sieger, R., Skjelvan, I., Sullivan, K. F., Sutherland, S. C., Sutton, A. J., Tadokoro, K., Telszewski, M., Tuma, M., van Heuven, S. M. A. C., Vandemark, D., Ward, B., Watson, A. J., and Xu, S.: A multidecade record of high-quality fCO2 data in version 3 of the Surface Ocean $\mathrm{CO}_{2}$ Atlas (SOCAT), Earth Syst. Sci. Data, 8, 383413, https://doi.org/10.5194/essd-8-383-2016, 2016.
Bathmann, U. V., Scharek, R., Klaas, C., Dubischar, C. D., and Smetacek, V.: Spring development of phytoplankton biomass and composition in major water masses of the Atlantic sector of the Southern Ocean, Deep-Sea Res. Pt. II, 44, 51-67, https://doi.org/10.1016/S0967-0645(96)00063-X, 1997.

Becquevort, S., Menon, P., and Lancelot, C.: Differences of the protozoan biomass and grazing during spring and summer in the Indian sector of the Southern Ocean, Polar. Biol., 23, 309-320, https://doi.org/10.1007/s003000050450, 2000.

Belkin, I. M. and Gordon, A. L.: Southern Ocean fronts from the Greenwich meridian to Tasmania, J. Geophys. Res.-Oceans, 101, 3675-3696, https://doi.org/10.1029/95JC02750, 1996.

Bendschneider, K. and Robinson, R. J.: A new spectrophotometric method for the determination of nitrite in sea water, 1952.

Bianchi, M., Feliatra, F., Tréguer, P., Vincendeau, M. A., and Morvan, J.: Nitrification rates, ammonium and nitrate distribution in upper layers of the water column and in sediments of the Indian sector of the Southern Ocean, Deep-Sea Res. Pt. II, 44, 1017 1032, https://doi.org/10.1016/S0967-0645(96)00109-9, 1997.

Billen, G.: Heterotrophic utilization and regeneration of nitrogen, in: Heterotrophic activity in the sea, NATO Conference Series (IV Marine Sciences), Boston, Massachusetts, United States of America, https://doi.org/10.1007/978-1-4684-9010-7_15, 1984.

Boyd, P. W., Crossley, A. C., DiTullio, G. R., Griffiths, F. B., Hutchins, D. A., Queguiner, B., Sedwick, P. N., and Trull, T. W.: Control of phytoplankton growth by iron supply and irradiance in the subantarctic Southern Ocean: Experimental results from the SAZ Project, J. Geophys. Res.-Oceans, 106, 31573-31583, https://doi.org/10.1029/2000JC000348, 2001.

Boyd, P. W., Rynearson, T. A., Armstrong, E. A., Fu, F., Hayashi, K., Hu, Z., Hutchins, D. A., Kudela, R. M., Litchman, E., Mulholland, M. R., Passow, U., Strzepek, R. F., Whittaker, K. A., Yu, E., and Thomas, M. K.: Marine Phytoplankton Temperature versus Growth Responses from Polar to Tropical Waters - Outcome of a Scientific Community-Wide Study, PLoS ONE, 8, 117, https://doi.org/10.1371/journal.pone.0063091, 2013.

Bracher, A. U., Kroon, B. M. A., and Lucas, M. I.: Primary production, physiological state and composition of phytoplankton in the Atlantic sector of the Southern Ocean, Mar. Ecol. Prog. Ser., 190, 1-16, https://doi.org/10.3354/meps 190001, 1999.

Broecker, W. S. and Peng, T. H.: Interhemispheric transport of carbon dioxide by ocean circulation, Nature, 356, 587-589, https://doi.org/10.1038/356587a0, 1992.

Buongiorno Nardelli, B., Guinehut, S., Verbrugge, N., Cotroneo, Y., Zambianchi, E., and Iudicone, D.: Southern Ocean mixedlayer seasonal and interannual variations from combined satellite and in situ data, J. Geophys. Res.-Oceans, 122, 10042-10060, https://doi.org/10.1002/2017JC013314, 2017.

Campitelli, E.: metR: Tools for Easier Analysis of Meteorological Fields, Zenodo [code], https://doi.org/10.5281/zenodo.2593516, 2019.

Carvalho, F., Kohut, J., Oliver, M. J., and Schofield, O.: Defining the ecologically relevant mixed-layer depth for Antarctica's coastal seas, Geophys. Res. Lett., 44, 338-345, https://doi.org/10.1002/2016GL071205, 2017.

Cavagna, A. J., Fripiat, F., Elskens, M., Mangion, P., Chirurgien, L., Closset, I., Lasbleiz, M., Florez-Leiva, L., Cardinal, D., Leblanc, K., Fernandez, C., Lefèvre, D., Oriol, L., Blain, S., Quéguiner, B., and Dehairs, F.: Production regime and associated 
$\mathrm{N}$ cycling in the vicinity of Kerguelen Island, Southern Ocean, Biogeosciences, 12, 6515-6528, https://doi.org/10.5194/bg-126515-2015, 2015.

Cavalieri, D. J. and Parkinson, C. L.: Antarctic sea ice variability and trends, 1979-2006, J. Geophys. Res.-Oceans, 113, C07004, https://doi.org/10.1029/2007JC004564, 2008.

Cavender-Bares, K. K., Mann, E. L., Chisholm, S. W., Ondrusek, M. E., and Bidigare, R. R.: Differential response of equatorial Pacific phytoplankton to iron fertilization, Limnol. Oceanogr., 44, 237246, https://doi.org/10.4319/lo.1999.44.2.0237, 1999.

Checkley Jr., D. M. and Miller, C. A.: Nitrogen isotope fractionation by oceanic zooplankton, Deep-Sea Res., 36, 1449-1456, https://doi.org/10.1016/0198-0149(89)90050-2, 1989.

Church, M. J., DeLong, E. F., Ducklow, H. W., Karner, M. B., Preston, C. M., and Karl, D. M.: Abundance and distribution of planktonic Archaea and Bacteria in the waters west of the Antarctic Peninsula, Limnol. Oceanogr., 48, 1893-1902, https://doi.org/10.4319/lo.2003.48.5.1893, 2003.

Coale, K. H., Gordon, R. M., and Wang, X.: The distribution and behaviour of dissolved and particulate iron and zinc in the Ross Sea and Antarctic circumpolar current along $170^{\circ} \mathrm{W}$, Deep-Sea Res. Pt. I, 52, 295-318, https://doi.org/10.1016/j.dsr.2004.09.008, 2005.

Cochlan, W. P.: Seasonal study of uptake and regeneration of nitrogen on the Scotian Shelf, Cont. Shelf. Res., 5, 555-577, https://doi.org/10.1016/0278-4343(86)90076-2, 1986.

Cochlan, W. P.: Nitrogen uptake in the Southern Ocean, in: Nitrogen in the Marine Environment, edited by: Capone, D. G., Bronk, D. A., Mulholland, M. R., and Carpenter, E. J., Academic Press, Elsevier, 569-596, https://doi.org/10.1016/B978-012-372522-6.00012-8, 2008.

Cochlan, W. P., Bronk, D. A., and Coale, K. H.: Trace metals and nitrogenous nutrition of Antarctic phytoplankton: experimental observations in the Ross Sea, Deep-Sea Res. Pt. II., 49, 33653390, https://doi.org/10.1016/S0967-0645(02)00088-7, 2002.

Coello-Camba, A. and Agustí, S.: Thermal thresholds of phytoplankton growth in polar waters and their consequences for a warming polar ocean, Front. Mar. Sci., 4, 168, https://doi.org/10.3389/fmars.2017.00168, 2017.

Cota, G. F., Smith, W. O., Nelson, D. M., Muench, R. D., and Gordon, L. I.: Nutrient and biogenic particulate distributions, primary productivity and nitrogen uptake in the Weddell-Scotia Sea marginal ice zone during winter, J. Mar. Res., 50, 155-181, https://doi.org/10.1357/002224092784797764, 1992.

Daly, K. L., Smith, W. O., Johnson, G. C., DiTullio, G. R., Jones, D. R., Mordy, C. W., Feely, R. A., Hansell, D. A., and Zhang, J.-Z.: Hydrography, nutrients, and carbon pools in the Pacific sector of the Southern Ocean: Implications for carbon flux, J. Geophys. Res.-Oceans, 106, 7107-7124, https://doi.org/10.1029/1999JC000090, 2001.

Deary, A.: A high-resolution study of the early- to late summer progression in primary production and carbon export potential in the Atlantic Southern Ocean, Honours thesis, University of Cape Town, South Africa, https://doi.org/10.5281/zenodo.5865488, 2020.

Dennett, M. R., Mathot, S., Caron, D. A., Smith, W. O., and Lonsdale, D. J.: Abundance and distribution of phototrophic and heterotrophic nano- and microplankton in the southern Ross Sea, Deep-Sea Res. Pt. II, 48, 4019-4037, https://doi.org/10.1016/S0967-0645(01)00079-0, 2001.

Deppeler, S. L. and Davidson, A. T.: Southern Ocean phytoplankton in a changing climate, Front. Mar. Sci., 4, 40, https://doi.org/10.3389/fmars.2017.00040, 2017.

Detmer, A. E. and Bathmann, U. V.: Distribution patterns of autotrophic pico-and nanoplankton and their relative contribution to algal biomass during spring in the Atlantic sector of the Southern Ocean, Deep-Sea Res. Pt. II, 44, 299-320, https://doi.org/10.1016/S0967-0645(96)00068-9, 1997.

Dong, S., Sprintall, J., Gille, S. T., and Talley, L.: Southern Ocean mixed-layer depth from Argo float profiles, J. Geophys. Res.Oceans, 113, C06013, https://doi.org/10.1029/2006JC004051, 2008.

Dortch, Q.: The interaction between ammonium and nitrate uptake in phytoplankton, Mar. Ecol. Prog. Ser., 61, 183-201, https://doi.org/10.3354/meps061183, 1990.

Dugdale, R. C. and Goering, J. J.: Uptake of new and regenerated forms of nitrogen in primary productivity, Limnol. Oceanogr., 12, 196-206, https://doi.org/10.4319/lo.1967.12.2.0196, 1967.

Dugdale, R. C. and Wilkerson, F. P.: The use of $15 \mathrm{~N}$ to measure nitrogen uptake in eutrophic oceans, experimental considerations 1, 2, Limnol. Oceanogr., 31, 673-689, https://doi.org/10.4319/lo.1986.31.4.0673, 1986.

Ellwood, M. J., Boyd, P. W., and Sutton, P.: Winter-time dissolved iron and nutrient distributions in the Subantarctic Zone from $40-52^{\circ} \mathrm{S} ; 155-160^{\circ} \mathrm{E}$, Geophys. Res. Lett., 35, https://doi.org/10.1029/2008GL033699, 2008.

Eppley, R. W. and Peterson, B. J.: Particulate organic matter flux and planktonic new production in the deep ocean, Nature, 282, 677-680, https://doi.org/10.1038/282677a0, 1979.

Fawcett, S. E. and Ward, B. B.: Phytoplankton succession and nitrogen utilization during the development of an upwelling bloom, Mar. Ecol. Prog. Ser., 428, 13-31, https://doi.org/10.3354/meps09070, 2011.

Fawcett, S. E., Lomas, M. W., Casey, J. R., Ward, B. B., and Sigman, D. M.: Assimilation of upwelled nitrate by small eukaryotes in the Sargasso Sea, Nat. Geosci., 4, 717-722, https://doi.org/10.1038/ngeo1265, 2011.

Fawcett, S. E., Lomas, M. W., Ward, B. B., and Sigman, D. M.: The counterintuitive effect of summer-to-fall mixed layer deepening on eukaryotic new production in the Sargasso Sea, Global Biogeochem. Cy., 28, 86-102, https://doi.org/10.1002/2013GB004579, 2014.

Fiala, M. and Oriol, L.: Light-temperature interactions on the growth of Antarctic diatoms, Polar. Biol., 10, 629-636, https://doi.org/10.1007/BF00239374, 1990.

Fiala, M., Semeneh, M., and Oriol, L.: Size-fractionated phytoplankton biomass and species composition in the Indian sector of the Southern Ocean during austral summer, J. Mar. Syst., 17, 179-194, https://doi.org/10.1016/S0924-7963(98)00037-2, 1998.

Finkel, Z. V., Irwin, A. J., and Schofield, O.: Resource limitation alters the $3 / 4$ size scaling of metabolic rates in phytoplankton, Mar. Ecol. Prog. Ser., 273, 269-279, https://doi.org/10.3354/meps273269, 2004.

Finley, A., Banerjee, S., and Hjelle, Ø.: MBA: Multilevel B-Spline Approximation, https://CRAN.R-project.org/package= MBA, 2017. 
Forsythe, W. C., Rykiel Jr., E. J., Stahl, R. S., Wu, H. I., and Schoolfield, R. M.: A model comparison for daylength as a function of latitude and day of year, Ecol. Model., 80, 87-95, https://doi.org/10.1016/0304-3800(94)00034-F, 1995.

Franck, V. M., Smith, G. J., Bruland, K. W., and Brzezinski, M. A.: Comparison of size-dependent carbon, nitrate, and silicic acid uptake rates in high-and low-iron waters, Limnol. Oceanogr., 50, 825-838, https://doi.org/10.4319/lo.2005.50.3.0825, 2005.

Francois, R., Altabet, M. A., and Burckle, L. H.: Glacial to interglacial changes in surface nitrate utilization in the Indian sector of the Southern Ocean as recorded by sediment $\delta 15 \mathrm{~N}$, Paleoceanography, 7, 589-606, https://doi.org/10.1029/92PA01573, 1992.

Fripiat, F., Elskens, M., Trull, T.W., Blain, S., Cavagna, A.J., Fernandez, C., Fonseca-Batista, D., Planchon, F., Raimbault, P., Roukaerts, A. and Dehairs, F.: Significant mixed layer nitrification in a natural iron-fertilized bloom of the Southern Ocean, Global Biogeochem. Cy., 29, 1929-1943, https://doi.org/10.1002/2014GB005051, 2015.

Fripiat, F., Martínez-García, A., Fawcett, S. E., Kemeny, P. C., Studer, A. S., Smart, S. M., Rubach, F., Oleynik, S., Sigman, D. M., and Haug, G. H.: The isotope effect of nitrate assimilation in the Antarctic Zone: Improved estimates and paleoceanographic implications, Geochim. Cosmochim. Ac., 247, 261-279, https://doi.org/10.1016/j.gca.2018.12.003, 2019.

Fripiat, F., Martínez-García, A., Marconi, D., Fawcett, S. E., Kopf, S., Luu, V., Rafter, P., Zhang, R., Sigman, D., and Haug, G.: Nitrogen isotopic constraints on nutrient transport to the upper ocean, Nat. Geosci., 14, 855-861, https://doi.org/10.1038/s41561-021-00836-8, 2021.

Frölicher, T. L., Sarmiento, J. L., Paynter, D. J., Dunne, J. P., Krasting, J. P., and Winton, M.: Dominance of the Southern Ocean in anthropogenic carbon and heat uptake in CMIP5 models, J. Climate, 28, 862-886, https://doi.org/10.1175/JCLI-D-14-00117.1, 2015.

Froneman, P. W., Ansorge, I. J., Pakhomov, E. A., and Lutjeharms, J. R. E.: Plankton community structure in the physical environment surrounding the Prince Edward Islands (Southern Ocean), Polar. Biol., 22, 145-155, https://doi.org/10.1007/s003000050404, 1999.

Fujiki, T. and Taguchi, S.: Variability in chlorophyll a specific absorption coefficient in marine phytoplankton as a function of cell size and irradiance, J. Plankton Res., 24, 859-874, https://doi.org/10.1093/plankt/24.9.859, 2002.

Gasol, J. M. and Giorgio, P. A.: Using flow cytometry for counting natural planktonic bacteria and understanding the structure of planktonic bacterial communities, Sci. Mar., 64, 197-224, https://doi.org/10.3989/scimar.2000.64n2197, 2000.

Gibson, J. A. and Trull, T. W.: Annual cycle of fCO2 under sea-ice and in open water in Prydz Bay, East Antarctica, Mar. Chem., 66, 187-200, https://doi.org/10.1016/S0304-4203(99)00040-7, 1999.

Glibert, P. M.: Regional studies of daily, seasonal and size fraction variability in ammonium remineralization, Mar. Biol., 70, 209222, https://doi.org/10.1007/BF00397687, 1982.

Goeyens, L., Tréguer, P., Lancelot, C., Mathot, S., Becquevort, S., Morvan, J., Dehairs, F., and Baeyens, W.: Ammonium regeneration in the Scotia-Weddell Confluence area during spring 1988, Mar. Ecol. Prog. Ser., 345-361, https://doi.org/10.3354/meps078241, 1991.

Goeyens, L., Tréguer, P., Baumann, M. E. M., Baeyens, W., and Dehairs, F.: The leading role of ammonium in the nitrogen uptake regime of Southern Ocean marginal ice zones, J. Mar. Syst., 6 , 345-361, https://doi.org/10.1016/0924-7963(94)00033-8, 1995.

Granger, J., Sigman, D. M., Needoba, J. A., and Harrison, P. J.: Coupled nitrogen and oxygen isotope fractionation of nitrate during assimilation by cultures of marine phytoplankton, Limnol. Oceanogr., 49, 1763-1773, https://doi.org/10.4319/lo.2004.49.5.1763, 2004.

Granger, J., Sigman, D. M., Rohde, M. M., Maldonado, M. T., and Tortell, P. D.: $\mathrm{N}$ and $\mathrm{O}$ isotope effects during nitrate assimilation by unicellular prokaryotic and eukaryotic plankton cultures, Geochim. Cosmochim. Ac., 74, 1030-1040, https://doi.org/10.1016/j.gca.2009.10.044, 2010.

Gray, A. R., Johnson, K. S., Bushinsky, S. M., Riser, S. C., Russell, J. L., Talley, L. D., Wanninkhof, R., Williams, N. L., and Sarmiento, J. L.: Autonomous biogeochemical floats detect significant carbon dioxide outgassing in the highlatitude Southern Ocean, Geophys. Res. Lett., 45, 9049-9057, https://doi.org/10.1029/2018GL078013, 2018.

Grolemund, G. and Wickham, H.: Dates and Times Made Easy with lubridate, J. Stat. Softw., 40, 1-25, https://www.jstatsoft.org/v40/ i03/, 2011.

Hasle, R. G.: The inverted microscope method, in: Phytoplankton manual, 88-96, 1978.

Hauck, J., Völker, C., Wolf-Gladrow, D. A., Laufkötter, C., Vogt, M., Aumont, O., Bopp, L., Buitenhuis, E. T., Doney, S. C., Dunne, J., and Gruber, N.: On the Southern Ocean $\mathrm{CO} 2$ uptake and the role of the biological carbon pump in the 21st century, Global Biogeochem. Cy., 29, 1451-1470, https://doi.org/10.1002/2015GB005140, 2015.

Henley, S. F., Tuerena, R. E., Annett, A. L., Fallick, A. E., Meredith, M. P., Venables, H. J., Clarke, A., and Ganeshram, R. S.: Macronutrient supply, uptake and recycling in the coastal ocean of the west Antarctic Peninsula, Deep-Sea Res. Pt. II, 139, 5876, https://doi.org/10.1016/j.dsr2.2016.10.003, 2017.

Henley, S. F., Cavan, E. L., Fawcett, S. E., Kerr, R., Monteiro, T., Sherrell, R. M., Bowie, A. R., Boyd, P. W. Barnes, D. K., Schloss, I. R., Marshall, T., Flynn, R., and Smith, S.: Changing biogeochemistry of the Southern Ocean and its ecosystem implications, Front. Mar. Sci., 7, 581, https://doi.org/10.3389/fmars.2020.00581, 2020.

Herbert, R. A.: Nitrogen cycling in coastal marine ecosystems, FEMS Microbiol. Rev., 23, 563-590, https://doi.org/10.1111/j.1574-6976.1999.tb00414.x, 1999.

Hewes, C. D., Holm-Hansen, O., and Sakshaug, E.: Alternate carbon pathways at lower trophic levels in the Antarctic food web, in: Antarctic nutrient cycles and food webs, edited by: Siegfried, W. R., Condy, P. R., Laws, R. M., Springer, Berlin, Heidelberg, 277-283, https://doi.org/10.1007/978-3-642-82275-9_40, 1985.

Hewes, C. D., Sakshaug, E., Reid, F. M., and Holm-Hansen, O.: Microbial autotrophic and heterotrophic eucaryotes in Antarctic waters: relationships between biomass and chlorophyll, adenosine triphosphate and particulate organic carbon, Mar. Ecol. Prog. Ser., 63, 27-36, 1990.

Hiscock, M. R., Marra, J., Smith Jr., W. O., Goericke, R., Measures, C., Vink, S., Olson, R. J., Sosik, H. M., and Barber, R. 
T.: Primary productivity and its regulation in the Pacific Sector of the Southern Ocean, Deep-Sea Res. Pt. II, 50, 533-558, https://doi.org/10.1016/S0967-0645(02)00583-0, 2003.

Holmes, R. M., Aminot, A., Kérouel, R., Hooker, B. A., and Peterson, B. J.: A simple and precise method for measuring ammonium in marine and freshwater ecosystems, Can. J. Fish. Aquat. Sci., 56, 1801-1808, https://doi.org/10.1139/f99-128, 1999.

Honjo, S., Francois, R., Manganini, S., Dymond, J., and Collier, R.: Particle fluxes to the interior of the Southern Ocean in the Western Pacific sector along 170 W, Deep-Sea Res. Pt. II, 47, 35213548, https://doi.org/10.1016/S0967-0645(00)00077-1, 2000.

Hooper, A. B. and Terry, K. R.: Photoinactivation of ammonia oxidation in Nitrosomonas, J. Bacteriol., 119, 899-906, https://doi.org/10.1128/jb.119.3.899-906.1974, 1974.

Horak, R. E., Qin, W., Schauer, A. J., Armbrust, E. V., Ingalls, A. E., Moffett, J. W., Stahl, D. A., and Devol, A. H.: Ammonia oxidation kinetics and temperature sensitivity of a natural marine community dominated by Archaea, ISME J., 7, 2023-2033, https://doi.org/10.1038/ismej.2013.75, 2013.

Horrigan, S. G. and Springer, A. L.: Oceanic and estuarine ammonium oxidation: Effects of light, Limnol. Oceanogr., 35, 479482, https://doi.org/10.4319/lo.1990.35.2.0479, 1990.

Hudson, R. J. and Morel, F. M.: Trace metal transport by marine microorganisms: implications of metal coordination kinetics, Deep-Sea Res. Pt. I, 40, 129-150, https://doi.org/10.1016/09670637(93)90057-A, 1993.

Iida, T. and Odate, T.: Seasonal variability of phytoplankton biomass and composition in the major water masses of the Indian Ocean sector of the Southern Ocean, Polar. Sci., 8, 283-297, https://doi.org/10.1016/j.polar.2014.03.003, 2014.

Ishikawa, A., Wright, S. W., Enden, R., Davidson, A. T., and Marchant, H. J.: Abundance, size structure and community composition of phytoplankton in the Southern Ocean in the austral summer 1999/2000, Polar Biogeosci., 15, 11-26, https://doi.org/10.15094/00006180, 2002.

Janssen, D. J., Sieber, M., Ellwood, M. J., Conway, T. M., Barrett, P. M., Chen, X., Souza, G. F., Hassler, C. S., and Jaccard, S. L.: Trace metal and nutrient dynamics across broad biogeochemical gradients in the Indian and Pacific sectors of the Southern Ocean, Mar. Chem., 221, 103773, https://doi.org/10.1016/j.marchem.2020.103773, 2020.

Jeong, H. J. and Latz, M. I.: Growth and grazing rates of the heterotrophic dinoflagellates Protoperidinium spp. on red tide dinoflagellates, Mar. Ecol. Prog. Ser., 106, 173-173, https://doi.org/10.3354/meps106173, 1994.

Jiang, H. B., Fu, F. X., Rivero-Calle, S., Levine, N. M., SañudoWilhelmy, S. A., Qu, P. P., Wang, X. W., Pinedo-Gonzalez, P., Zhu, Z., and Hutchins, D. A.: Ocean warming alleviates iron limitation of marine nitrogen fixation, Nat. Clim. Change, 8, 709712, https://doi.org/10.1038/s41558-018-0216-8, 2018.

Johnson, K. S., Plant, J. N., Dunne, J. P., Talley, L. D., and Sarmiento, J. L.: Annual nitrate drawdown observed by SOCCOM profiling floats and the relationship to annual net community production, J. Geophys. Res.-Oceans, 122, 6668-6683, https://doi.org/10.1002/2017JC012839, 2017.

Joubert, W. R., Thomalla, S. J., Waldron, H. N., Lucas, M. I., Boye, M., Le Moigne, F. A. C., Planchon, F., and Speich, S.: Nitrogen uptake by phytoplankton in the Atlantic sector of the South- ern Ocean during late austral summer, Biogeosciences, 8, 29472959, https://doi.org/10.5194/bg-8-2947-2011, 2011.

Kassambara, A.: ggpubr: "ggplot2" Based Publication Ready Plots, https://CRAN.R-project.org/package=ggpubr, 2019.

Kattner, G., Thomas, D. N., Haas, C., Kennedy, H., and Dieckmann, G. S.: Surface ice and gap layers in Antarctic sea ice: highly productive habitats, Mar. Ecol. Prog. Ser., 277, 1-12, https://doi.org/10.3354/meps277001, 2004.

Kelley, D. and Richards, C.: oce: Analysis of Oceanographic Data, R package version 1.5-0, https://dankelley.github.io/oce/, 2022.

Kirchman, D. L.: The Uptake of Inorganic Nutrients by Heterotrophic Bacteria, Microb. Ecol., 28, 255-271, https://doi.org/10.1007/BF00166816, 1994.

Kitzinger, K., Padilla, C. C., Marchant, H. K., Hach, P. F., Herbold, C. W., Kidane, A. T., Könneke, M., Littmann, S., Mooshammer, M., Niggemann, J., and Petrov, S.: Cyanate and urea are substrates for nitrification by Thaumarchaeota in the marine environment, Nat. Microbiol., 4, 234-243, https://doi.org/10.1038/s41564-018-0316-2, 2019.

Klawonn, I., Bonaglia, S., Whitehouse, M. J., Littmann, S., Tienken, D., Kuypers, M. M., Brüchert, V., and Ploug, H.: Untangling hidden nutrient dynamics: rapid ammonium cycling and single-cell ammonium assimilation in marine plankton communities, ISME J., 13, 1960-1974, https://doi.org/10.1038/s41396-019-0386-Z, 2019.

Knapp, A. N., Dekaezemacker, J., Bonnet, S., Sohm, J. A., and Capone, D. G.: Sensitivity of Trichodesmium erythraeum and Crocosphaera watsonii abundance and $\mathrm{N}_{2}$ fixation rates to varying $\mathrm{NO}_{3}^{-}$and $\mathrm{PO}_{4}^{3-}$ concentrations in batch cultures, Aquat. Microb. Ecol., 66, 223-236, https://doi.org/10.3354/ame01577, 2012.

Kobayashi, F. and Takahashi, K.: Distribution of diatoms along the equatorial transect in the western and central Pacific during the 1999 La Niña conditions, Deep-Sea Res. Pt. II, 49, 2801-2821, https://doi.org/10.1016/S0967-0645(02)00059-0, 2002.

Koike, I., Holm-Hansen, O., and Biggs, D. C.: Phytoplankton With Special Reference To Ammonium Cycling, Mar. Ecol., 30, 105116, https://doi.org/10.3354/meps030105, 1986.

Kopczyńska, E. E., Savoye, N., Dehairs, F., Cardinal, D., and Elskens, M.: Spring phytoplankton assemblages in the Southern Ocean between Australia and Antarctica, Polar. Biol., 31, 77-88, https://doi.org/10.1007/s00300-007-0335-6, 2007.

Kottmeier, S. T. and Sullivan, C. W.: Late winter primary production and bacterial production in sea ice and seawater west of the Antarctic Peninsula, Mar. Ecol. Prog. Ser., 36, 287-298, https://doi.org/10.3354/meps036287, 1987.

Kustka, A. B., Sañudo-Wilhelmy, S. A., Carpenter, E. J., Capone, D., Burns, J., and Sunda, W. G.: Iron requirements for dinitrogenand ammonium-supported growth in cultures of Trichodesmium (IMS 101): Comparison with nitrogen fixation rates and iron: Carbon ratios of field populations, Limnol. Oceanogr., 48, 18691884, https://doi.org/10.4319/lo.2003.48.5.1869, 2003.

La Roche, J.: Ammonium regeneration: its contribution to phytoplankton nitrogen requirements in a eutrophic environment, Mar Biol., 75, 231-240, https://doi.org/10.1007/BF00406007, 1983.

Lauderdale, J. M., Garabato, A. C. N., Oliver, K. I., Follows, M. J., and Williams, R. G.: Wind-driven changes in Southern Ocean residual circulation, ocean carbon reser- 
voirs and atmospheric CO2, Clim. Dynam., 41, 2145-2164, https://doi.org/10.1007/s00382-012-1650-3, 2013.

Le Moigne, F. A. C., Boye, M., Masson, A., Corvaisier, R., Grossteffan, E., Guéneugues, A., and Pondaven, P.: Description of the biogeochemical features of the subtropical southeastern Atlantic and the Southern Ocean south of South Africa during the austral summer of the International Polar Year, Biogeosciences, 10, 281-295, https://doi.org/10.5194/bg-10-281-2013, 2013.

Lee, S. H., Joo, H. M., Liu, Z., Chen, J., and He, J.: Phytoplankton productivity in newly opened waters of the Western Arctic Ocean, Deep-Sea Res. Pt. II, 81, 18-27, https://doi.org/10.1016/j.dsr2.2011.06.005, 2012.

Lee, S. H., Yun, M. S., Kim, B. K., Joo, H., Kang, S. H., Kang, C. K., and Whitledge, T. E.: Contribution of small phytoplankton to total primary production in the Chukchi Sea, Cont. Shelf. Res., 68, 43-50, https://doi.org/10.1016/j.csr.2013.08.008, 2013.

Legrand, M., Ducroz, F., Wagenbach, D., Mulvaney, R., and Hall, J.: Ammonium in coastal Antarctic aerosol and snow: Role of polar ocean and penguin emissions, J. Geophys. Res.-Atmos., 103, 11043-11056, https://doi.org/10.1029/97JD01976, 1998.

Lehette, P., Tovar-Sánchez, A., Duarte, C. M., and Hernández-León, S.: Krill excretion and its effect on primary production, Mar. Ecol. Prog. Ser., 459, 29-38, https://doi.org/10.3354/meps09746, 2012.

Lipschultz, F.: Isotope tracer methods for studies of the marine nitrogen cycle, in: Nitrogen in the Marine Environment, 2nd ed., edited by: Capone, D. G., Bronk, D. A., Mulholland, M. R., and Carpenter, E. J., Academic Press, Burlington, Massachusetts, United States of America, https://doi.org/10.1016/B978-0-12372522-6.00031-1, 2008.

Llort, J., Lévy, M., Sallée, J. B., and Tagliabue, A.: Nonmonotonic response of primary production and export to changes in mixed-layer depth in the Southern Ocean, Geophys. Res. Lett., 46, 3368-3377, https://doi.org/10.1029/2018GL081788, 2019.

Lourey, M. J., Trull, T. W., and Sigman, D. M.: Sensitivity of $\delta 15 \mathrm{~N}$ of nitrate, surface suspended and deep sinking particulate nitrogen to seasonal nitrate depletion in the Southern Ocean, Global Biogeochem. Cy., 17, 1081, https://doi.org/10.1029/2002GB001973, 2003.

Lu, S., Liu, X., Liu, C., Cheng, G., and Shen, H.: Influence of photoinhibition on nitrification by ammonia-oxidizing microorganisms in aquatic ecosystems, Rev. Environ. Sci. Bio., 19, 531-542, https://doi.org/10.1007/s11157-020-09540-2, 2020.

Lutjeharms, J. R. E. and Valentine, H. R.: Southern ocean thermal fronts south of Africa, Deep-Sea Res., 31, 1461-1475, https://doi.org/10.1016/0198-0149(84)90082-7, 1984.

Macko, S. A., Estep, M. L. F., Engel, M. H., and Hare, P. E.: Kinetic fractionation of stable nitrogen isotopes during amino acid transamination, Geochim. Cosmochim. Ac., 50, 2143-2146, https://doi.org/10.1016/0016-7037(86)90068-2, 1986.

Maldonado, M. T., Allen, A. E., Chong, J. S., Lin, K., Leus, D., Karpenko, N., and Harris, S. L.: Copper-dependent iron transport in coastal and oceanic diatoms, Limnol. Oceanogr., 51, 17291743, https://doi.org/10.4319/lo.2006.51.4.1729, 2006.

Marie, D., Partensky, F., Jacquet, S., and Vaulot, D.: Enumeration and cell cycle analysis of natural populations of marine picoplankton by flow cytometry using the nucleic acid stain SYBR Green I, Appl. Environ. Microb., 63, 186-193, https://doi.org/10.1128/aem.63.1.186-193.1997, 1997.
Marie, D., Simon, N., and Vaulot, D.: Phytoplankton cell counting by flow cytometry, Algal Culturing Techniques, 1, 253-267, https://doi.org/10.1016/B978-012088426-1/50018-4, 2005.

Martin, J. H., Fitzwater, S. E., and Gordon, R. M.: Iron deficiency limits phytoplankton growth in Antarctic waters, Global Biogeochem. Cy., 4, 5-12, https://doi.org/10.1029/GB004i001p00005, 1990.

Mayzaud, P., Razouls, S., Errhif, A., Tirelli, V., and Labat, J. P.: Feeding, respiration and egg production rates of copepods during austral spring in the Indian sector of the Antarctic Ocean: role of the zooplankton community in carbon transformation, DeepSea Res. Pt. I, 49, 1027-1048, https://doi.org/10.1016/S09670637(02)00012-2, 2002.

McIlvin, M. R. and Altabet, M. A.: Chemical conversion of nitrate and nitrite to nitrous oxide for nitrogen and oxygen isotopic analysis in freshwater and seawater, Anal. Chem., 77, 5589-5595, https://doi.org/10.1021/ac050528s, 2005.

McIlvin, M. R. and Casciotti, K. L.: Technical updates to the bacterial method for nitrate isotopic analyses, Anal. Chem., 83, 18501856, https://doi.org/10.1021/ac1028984, 2011.

Mdutyana, M.: Mixed layer nitrogen cycling in the Southern Ocean: seasonality, kinetics, and biogeochemical implications, Ph.D. dissertation, University of Cape Town, South Africa, https://doi.org/10.5281/zenodo.5865349, 2021.

Mdutyana, M., Thomalla, S. J., Philibert, R., Ward, B. B., and Fawcett, S. E.: The seasonal cycle of nitrogen uptake and nitrification in the Atlantic sector of the Southern Ocean, Global Biogeochem. Cy., 34, 006363, https://doi.org/10.1029/2019GB006363, 2020.

Mei, Z. P., Finkel, Z. V., and Irwin, A. J.: Light and nutrient availability affect the size-scaling of growth in phytoplankton, J. Theor. Biol., 259, 582-588, https://doi.org/10.1016/j.jtbi.2009.04.018, 2009.

Mengesha, S., Dehairs, F., Fiala, M., Elskens, M., and Goeyens, L.: Seasonal variation of phytoplankton community structure and nitrogen uptake regime in the Indian Sector of the Southern Ocean, Polar. Biol., 20, 259-272, https://doi.org/10.1007/s003000050302, 1998.

Möbius, J.: Isotope fractionation during nitrogen remineralization (ammonification): Implications for nitrogen isotope biogeochemistry, Geochim. Cosmochim. Ac., 105, 422-432, https://doi.org/10.1016/j.gca.2012.11.048, 2013.

Mongwe, N. P., Vichi, M., and Monteiro, P. M. S.: The seasonal cycle of $p \mathrm{CO}_{2}$ and $\mathrm{CO}_{2}$ fluxes in the Southern Ocean: diagnosing anomalies in CMIP5 Earth system models, Biogeosciences, 15, 2851-2872, https://doi.org/10.5194/bg-15-2851-2018, 2018.

Mordy, C. W., Penny, D. M., and Sullivan, C. W.: Spatial distribution of bacterioplankton biomass and production in the marginal ice-edge zone of the Weddell-Scotia Sea during austral winter, Mar. Ecol. Prog. Ser., 122, 9-19, https://doi.org/10.3354/meps122009, 1995.

Morel, F. M., Hudson, R. J., and Price, N. M.: Limitation of productivity by trace metals in the sea, Limnol. Oceanogr., 36, 1742 1755, https://doi.org/10.4319/lo.1991.36.8.1742, 1991.

Mtshali, T. N., Horsten, N. R., Thomalla, S. J., Ryan-Keogh, T. J., Nicholson, S. A., Roychoudhury, A. N., Bucciarelli, E., Sarthou, G., Tagliabue, A., and Monteiro, P. M.: Seasonal depletion of the dissolved iron reservoirs in the sub-Antarctic zone of the 
Southern Atlantic Ocean, Geophys. Res. Lett., 46, 4386-4395, https://doi.org/10.1029/2018GL081355, 2019.

Murphy, J. and Riley, J. P.: A modified single solution method for the determination of phosphate in natural waters, Anal. Chim. Acta, 27, 31-36, https://doi.org/10.1016/S0003-2670(00)88444$5,1962$.

Nelson, D. M., Brzezinski, M. A., Sigmon, D. E., and Franck, V. M.: A seasonal progression of Si limitation in the Pacific sector of the Southern Ocean, Deep-Sea Res. Pt. II, 48, 3973-3995, https://doi.org/10.1016/S0967-0645(01)00076-5, 2001.

Nicholson, S. A., Lévy, M., Jouanno, J., Capet, X., Swart, S., and Monteiro, P. M.: Iron supply pathways between the surface and subsurface waters of the Southern Ocean: from winter entrainment to summer storms, Geophys. Res. Lett., 46, 14567-14575, https://doi.org/10.1029/2019GL084657, 2019.

Olson, R. J.: Differential photoinhibition of marine nitrifying bacteria: a possible mechanism for the formation of the primary nitrite maximum, J. Mar. Res., 39, 227-238, 1981.

Orsi, A. H., Whitworth, T., and Nowlin, W. D.: On the meridional extent and fronts of the Antarctic Circumpolar Current, Deep-Sea Res. Pt. I, 42, 641-673, https://doi.org/10.1016/09670637(95)00021-W, 1995.

Painter, S. C., Patey, M. D., Tarran, G. A., and Torres-Valdés, S.: Picoeukaryote distribution in relation to nitrate uptake in the oceanic nitracline, Aquat. Microb. Ecol., 72, 195-213, https://doi.org/10.3354/ame01695, 2014.

Paulot, F., Jacob, D. J., Johnson, M. T., Bell, T. G., Baker, A. R., Keene, W. C., Lima, I. D., Doney, S. C., and Stock, C. A.: Global oceanic emission of ammonia: Constraints from seawater and atmospheric observations, Global Biogeochem. Cy., 29, 11651178, https://doi.org/10.1002/2015GB005106, 2015.

Pausch, F., Bischof, K., and Trimborn, S.: Iron and manganese co-limit growth of the Southern Ocean diatom Chaetoceros debilis, PLoS ONE, 14, 0221959, https://doi.org/10.1371/journal.pone.0221959, 2019.

Pearce, I., Davidson, A. T., Thomson, P. G., Wright, S., and Enden, R.: Marine microbial ecology off East Antarctica (30$80^{\circ} \mathrm{E}$ ): Rates of bacterial and phytoplankton growth and grazing by heterotrophic protists, Deep-Sea Res. Pt. II, 57, 849-862, https://doi.org/10.1016/j.dsr2.2008.04.039, 2010.

Peng, X., Fuchsman, C. A., Jayakumar, A., Oleynik, S., Martens-Habbena, W., Devol, A. H., and Ward, B. B.: Ammonia and nitrite oxidation in the Eastern Tropical North Pacific, Global Biogeochem. Cy., 29, 2034-2049, https://doi.org/10.1002/2015GB005278, 2015.

Philibert, R., Waldron, H., and Clark, D.: A geographical and seasonal comparison of nitrogen uptake by phytoplankton in the Southern Ocean, Ocean Sci., 11, 251-267, https://doi.org/10.5194/os-11-251-2015, 2015.

Plate, T. and Heiberger, R.: abind: Combine multi-dimensional arrays v1.1, https://CRAN.R-project.org/package=abind, 2019.

Pomeroy, L. R. and Wiebe, W. J.: Temperature and substrates as interactive limiting factors for marine heterotrophic bacteria, Aquat. Microb. Ecol., 23, 187-204, https://doi.org/10.3354/ame023187, 2001.

Prézelin, B. B., Hofmann, E. E., Mengelt, C., and Klinck, J. M.: The linkage between Upper Circumpolar Deep Water (UCDW) and phytoplankton assemblages on the west Antarc- tic Peninsula continental shelf, J. Mar. Res., 58, 165-202, https://doi.org/10.1357/002224000321511133, 2000.

Price, N. M., Ahner, B. A., and Morel, F. M.: The equatorial Pacific Ocean: Grazer-controlled phytoplankton populations in an iron-limited ecosystem 1, Limnol. Oceanogr., 39, 520-534, https://doi.org/10.4319/lo.1994.39.3.0520, 1994.

Priddle, J., Nedwell, D. B., Whitehouse, M. J., Reay, D. S., Savidge, G., Gilpin, L. C., Murphy, E. J., and Ellis-Evans, J. C.: Reexamining the Antarctic Paradox: speculation on the Southern Ocean as a nutrient-limited system, Ann. Glaciol., 27, 661-668, https://doi.org/10.3189/1998AoG27-1-661-668, 1998.

Primeau, F. W., Holzer, M., and DeVries, T.: Southern Ocean nutrient trapping and the efficiency of the biological pump, J. Geophys. Res.-Oceans, 118, 2547-2564, https://doi.org/10.1002/jgrc.20181, 2013.

R Core Team: R: A language and environment for statistical computing, https://www.R-project.org/, 2020.

Raven, J. A.: The iron and molybdenum use efficiencies of plant growth with different energy, carbon and nitrogen sources, New Phytol., 109, 279-287, https://doi.org/10.1111/j.14698137.1988.tb04196.x, 1988.

Reay, D. S., Priddle, J., Nedwell, D. B., Whitehouse, M. J., EllisEvans, J. C., Deubert, C., and Connelly, D. P.: Regulation by low temperature of phytoplankton growth and nutrient uptake in the Southern Ocean, Mar. Ecol. Prog. Ser., 219, 51-64, https://doi.org/10.3354/meps219051, 2001.

Rembauville, M., Briggs, N., Ardyna, M., Uitz, J., Catala, P., Penkerc'h, C., Poteau, A., Claustre, H., and Blain, S. Plankton assemblage estimated with BGC-Argo floats in the Southern Ocean: Implications for seasonal successions and particle export, J. Geophys. Res.-Oceans, 122, 8278-8292, https://doi.org/10.1002/2017JC013067, 2017.

Ren, H., Sigman, D. M., Thunell, R. C., and Prokopenko, M. G.: Nitrogen isotopic composition of planktonic foraminifera from the modern ocean and recent sediments, Limnol. Oceanogr., 57, 1011-1024, https://doi.org/10.4319/lo.2012.57.4.1011, 2012.

Revilla, M., Alexander, J., and Glibert, P. M.: Urea analysis in coastal waters: comparison of enzymatic and direct methods, Limnol. Oceanogr.-Meth., 3, 290-299, https://doi.org/10.4319/lom.2005.3.290, 2005.

Rintoul, S. R. and Trull, T. W.: Seasonal evolution of the mixed layer in the Subantarctic Zone south of Australia, J. Geophys. Res.-Oceans, 106, 31447-31462, https://doi.org/10.1029/2000JC000329, 2001.

Sallée, J. B., Speer, K. G., and Rintoul, S. R.: Zonally asymmetric response of the Southern Ocean mixed-layer depth to the Southern Annular Mode, Nat. Geosci., 3, 273-279, https://doi.org/10.1038/ngeo812, 2010.

Sambrotto, R. N. and Mace, B. J.: Coupling of biological and physical regimes across the Antarctic Polar Front as reflected by nitrogen production and recycling, Deep-Sea Res. Pt. II, 47, 3339 3367, https://doi.org/10.1016/S0967-0645(00)00071-0, 2000.

Santoro, A. E., Sakamoto, C. M., Smith, J. M., Plant, J. N., Gehman, A. L., Worden, A. Z., Johnson, K. S., Francis, C. A., and Casciotti, K. L.: Measurements of nitrite production in and around the primary nitrite maximum in the central California Current, Biogeosciences, 10, 7395-7410, https://doi.org/10.5194/bg-107395-2013, 2013. 
Sarmiento, J. L. and Orr, J. C.: Three-dimensional simulations of the impact of Southern Ocean nutrient depletion on atmospheric CO2 and ocean chemistry, Limnol. Oceanogr., 36, 1928-1950, https://doi.org/10.4319/lo.1991.36.8.1928, 1991.

Sarmiento, J. L. and Toggweiler, J. R.: A new model for the role of the oceans in determining atmospheric pCO2, Nature, 308, 621624, https://doi.org/10.1038/308621a0, 1984.

Sarmiento, J. L., Gruber, N., Brzezinski, M. A., and Dunne, J. P.: High-latitude controls of thermocline nutrients and low latitude biological productivity, Nature, 427, 56-60, https://doi.org/10.1038/nature02127, 2004.

Savoye, N., Dehairs, F., Elskens, M., Cardinal, D., Kopczyńska, E. E., Trull, T. W., Wright, S., Baeyens, W., and Griffiths, F. $\mathrm{B}$.: Regional variation of spring $\mathrm{N}$-uptake and new production in the Southern Ocean, Geophys. Res. Lett., 31, L03301, https://doi.org/10.1029/2003GL018946, 2004.

Schaafsma, F. L., Cherel, Y., Flores, H., Franeker, J. A., Lea, M. A., Raymond, B., and Putte, A. P.: Review: the energetic value of zooplankton and nekton species of the Southern Ocean, Mar. Biol., 165, 1-35, https://doi.org/10.1007/s00227-018-3386z, 2018 .

Sedwick, P. N., Bowie, A. R., and Trull, T. W.: Dissolved iron in the Australian sector of the Southern Ocean (CLIVAR SR3 section): Meridional and seasonal trends, Deep-Sea Res. Pt. I, 55, 911925, https://doi.org/10.1016/j.dsr.2008.03.011, 2008.

Semeneh, M., Dehairs, F., Elskens, M., Baumann, M. E. M., Kopczynska, E. E., Lancelot, C., and Goeyens, L.: Nitrogen uptake regime and phytoplankton community structure in the Atlantic and Indian sectors of the Southern Ocean, J. Mar. Syst., 17, 159-177, https://doi.org/10.1016/S0924-7963(98)00036-0, 1998.

Serebrennikova, Y. M. and Fanning, K. A.: Nutrients in the Southern Ocean GLOBEC region: Variations, water circulation, and cycling, Deep-Sea Res. Pt. II, 51, 1981-2002, https://doi.org/10.1016/j.dsr2.2004.07.023, 2004.

Shadwick, E. H., Trull, T. W., Tilbrook, B., Sutton, A. J., Schulz, E., and Sabine, C. L.: Seasonality of biological and physical controls on surface ocean $\mathrm{CO} 2$ from hourly observations at the Southern Ocean Time Series site south of Australia, Global Biogeochem. Cy., 29, 223-238, https://doi.org/10.1002/2014GB004906, 2015.

Shafiee, R. T., Snow, J. T., Zhang, Q., and Rickaby, R. E.: Iron requirements and uptake strategies of the globally abundant marine ammonia-oxidising archaeon, Nitrosopumilus maritimus SCM1, ISME J., 13, 2295-2305, https://doi.org/10.1038/s41396-0190434-8, 2019.

Shiozaki, T., Fujiwara, A., Ijichi, M., Harada, N., Nishino, S., Nishi, S., Nagata, T., and Hamasaki, K.: Diazotroph community structure and the role of nitrogen fixation in the nitrogen cycle in the Chukchi Sea (western Arctic Ocean), Limnol. Oceanogr., 63, 2191-2205, https://doi.org/10.1002/lno.10933, 2018.

Sigman, D. M. and Boyle, E. A.: Glacial/interglacial variations in atmospheric carbon dioxide, Nature, 407, 859-869, https://doi.org/10.1038/35038000, 2000.

Sigman, D. M., Altabet, M. A., McCorkle, D. C., Francois, R., and Fischer, G.: The $\delta 15 \mathrm{~N}$ of nitrate in the southern ocean: Consumption of nitrate in surface waters, Global Biogeochem. Cy., 13, 1149-1166, https://doi.org/10.1029/1999GB900038, 1999.

Smart, S. M., Fawcett, S. E., Thomalla, S. J., Weigand, M. A., Reason, C. J. C., and Sigman, D. M.: Isotopic evidence for nitrifi- cation in the Antarctic winter mixed layer, Global Biogeochem. Cy., 29, 427-445, https://doi.org/10.1002/2014GB005013, 2015.

Smart, S. M., Fawcett, S. E., Ren, H., Schiebel, R., Tompkins, E. M., Martínez-García, A., Stirnimann, L., Roychoudhury, A., Haug, G. H., and Sigman, D. M.: The Nitrogen Isotopic Composition of Tissue and Shell-Bound Organic Matter of Planktic Foraminifera in Southern Ocean Surface Waters, Geochem. Geophy. Geosy., 21, e2019GC008440, https://doi.org/10.1029/2019GC008440, 2020.

Smith, S.: Biogeochemical data - 2017 Winter Cruise Atlantic-Indian Southern Ocean, Zenodo [data set], https://doi.org/10.5281/zenodo.3884606, 2020.

Smith, J. M., Chavez, F. P., and Francis, C. A.: Ammonium Uptake by Phytoplankton Regulates Nitrification in the Sunlit Ocean, PLoS ONE, 9, 108173, https://doi.org/10.1371/journal.pone.0108173, 2014.

Smith Jr., W. O. and Harrison, W. G.: New production in polar regions: the role of environmental controls, Deep-Sea Res., 38, 1463-1479, https://doi.org/10.1016/0198-0149(91)90085-T, 1991.

Smith Jr., W. O., Marra, J., Hiscock, M. R. and Barber, R. T.: The seasonal cycle of phytoplankton biomass and primary productivity in the Ross Sea, Antarctica, Deep-Sea Res. Pt. II, 47, 3119 3140, https://doi.org/10.1016/S0967-0645(00)00061-8, 2000.

Smith Jr., W. O. and Lancelot, C.: Bottom-up versus top-down control in phytoplankton of the Southern Ocean, Antarct. Sci., 16, 531, https://doi.org/10.1017/S0954102004002305, 2004.

Soares, M. A., Bhaskar, P. V., Naik, R. K., Dessai, D., George, J., Tiwari, M., and Anilkumar, N.: Latitudinal $\delta 13 \mathrm{C}$ and $\delta 15 \mathrm{~N}$ variations in particulate organic matter $(\mathrm{POM})$ in surface waters from the Indian ocean sector of Southern Ocean and the Tropical Indian Ocean in 2012, Deep-Sea Res. Pt. II, 118, 186-196, https://doi.org/10.1016/j.dsr2.2015.06.009, 2015.

Sokolov, S. and Rintoul, S. R.: On the relationship between fronts of the Antarctic Circumpolar Current and surface chlorophyll concentrations in the Southern Ocean, J. Geophys. Res.-Oceans, 112, C07030, https://doi.org/10.1029/2006JC004072, 2007.

Sosik, H. M. and Olson, R. J.: Phytoplankton and iron limitation of photosynthetic efficiency in the Southern Ocean during late summer, Deep-Sea Res. Pt. I, 49, 1195-1216, https://doi.org/10.1016/S0967-0637(02)00015-8, 2002.

Steinberg, D. K. and Saba, G. K.: Nitrogen consumption and metabolism in marine zooplankton, in: Nitrogen in the marine environment, edited by: Capone, D. G., Bronk, D. A., Mulholland, M. R., and Carpenter, E. J., Elsevier Inc, 1135-1196, https://doi.org/10.1016/B978-0-12-372522-6.00026-8, 2008.

Strickland, J. D. H. and Parsons, T. R. (Eds.): A practical handbook of seawater analysis, 2nd edition, Fisheries Research Board of Canada, Bulletin 167, Ottawa, 1972.

Sunda, W. G. and Huntsman, S. A.: Interrelated influence of iron, light and cell size on marine phytoplankton growth, Nature, 390, 389-392, https://doi.org/10.1038/37093, 1997.

Tagliabue, A., Mtshali, T., Aumont, O., Bowie, A. R., Klunder, M. B., Roychoudhury, A. N., and Swart, S.: A global compilation of dissolved iron measurements: focus on distributions and processes in the Southern Ocean, Biogeosciences, 9, 2333-2349, https://doi.org/10.5194/bg-9-2333-2012, 2012.

Tagliabue, A., Sallée, J. B., Bowie, A. R., Lévy, M., Swart, S., and Boyd, P. W.: Surface-water iron supplies in the Southern 
Ocean sustained by deep winter mixing, Nat. Geosci., 7, 314320, https://doi.org/10.1038/ngeo2101, 2014.

Takao, S., Hirawake, T., Wright, S. W., and Suzuki, K.: Variations of net primary productivity and phytoplankton community composition in the Indian sector of the Southern Ocean as estimated from ocean color remote sensing data, Biogeosciences, 9, 38753890, https://doi.org/10.5194/bg-9-3875-2012, 2012.

Tevlin, A. G. and Murphy, J. G.: Atmospheric Ammonia: Measurements, Modeling, and Chemistry-Climate Interactions, in: Advances In Atmospheric Chemistry-Volume 2: Organic Oxidation And Multiphase Chemistry, edited by: Barker, J. R., Steiner, A. L., and Wallington, T. J., 2, 1, https://doi.org/10.1142/9789813271838_0001, 2019.

Thomalla, S. J., Waldron, H. N., Lucas, M. I., Read, J. F., Ansorge, I. J., and Pakhomov, E.: Phytoplankton distribution and nitrogen dynamics in the southwest indian subtropical gyre and Southern Ocean waters, Ocean Sci., 7, 113-127, https://doi.org/10.5194/os-7-113-2011, 2011.

Timmermans, K. R., Van Leeuwe, M. A., De Jong, J. T. M., McKay, R. M. L., Nolting, R. F., Witte, H. J., Van Ooyen, J., Swagerman, M. J. W., Kloosterhuis, H., and De Baar, H. J.: Iron stress in the Pacific region of the Southern Ocean: evidence from enrichment bioassays, Mar. Ecol. Prog. Ser., 166, 27-41, https://doi.org/10.3354/meps166027, 1998.

Tréguer, P. and Jacques, G.: Review Dynamics of nutrients and phytoplankton, and fluxes of carbon, nitrogen and silicon in the Antarctic Ocean, in: Weddell Sea Ecology, edited by: Hempel, G., Springer, Berlin, Heidelberg, 149-162, https://doi.org/10.1007/978-3-642-77595-6, 1992.

Treibergs, L. A., Fawcett, S. E., Lomas, M. W., and Sigman, D. M.: Nitrogen isotopic response of prokaryotic and eukaryotic phytoplankton to nitrate availability in Sargasso Sea surface waters, Limnol. Oceanogr., 59, 972-985, https://doi.org/10.4319/lo.2014.59.3.0972, 2014.

Trull, T. W., Davies, D., and Casciotti, K.: Insights into nutrient assimilation and export in naturally iron-fertilized waters of the Southern Ocean from nitrogen, carbon and oxygen isotopes, Deep-Sea Res. Pt. II, 55, 820-840, https://doi.org/10.1016/j.dsr2.2007.12.035, 2008.

Tupas, L. and Koike, I.: Amino acid and ammonium utilization by heterotrophic marine bacteria grown in enriched seawater, Limnol. Oceanogr., 35, 1145-1155, https://doi.org/10.4319/lo.1990.35.5.1145, 1990.

Utermöhl, H.: Zur vervollkommnung der quantitativen phytoplankton-methodik: mit 1 Tabelle und 15 abbildungen im Text und auf 1 Tafel, Internationale Vereinigung für theoretische und angewandte Limnologie: Mitteilungen, 9, 1-38, 1958.

Vaulot, D., Courties, C., and Partensky, F.: A simple method to preserve oceanic phytoplankton for flow cytometric analyses, Cytometry, 10, 629-635, https://doi.org/10.1002/cyto.990100519, 1989.

Viljoen, J. J., Weir, I., Fietz, S., Cloete, R., Loock, J., Philibert, R., and Roychoudhury, A. N.: Links between the phytoplankton community composition and trace metal distribution in summer surface waters of the Atlantic southern ocean, Front. Mar. Sci., 6, 295, https://doi.org/10.3389/fmars.2019.00295, 2019.

Volk, T. and Hoffert, M. I.: Ocean carbon pumps: Analysis of relative strengths and efficiencies in ocean-driven atmospheric $\mathrm{CO} 2$ changes, in: The carbon cycle and atmospheric $\mathrm{CO} 2$ : natural variations Archean to present, edited by: Sundquist, E., and Broecker, W., 32, 99-110, https://doi.org/10.1029/GM032p0099, 1985.

Wadley, M. R., Jickells, T. D., and Heywood, K. J.: The role of iron sources and transport for Southern Ocean productivity, Deep-Sea Res. Pt. I, 87, 82-94, https://doi.org/10.1016/j.dsr.2014.02.003, 2014.

Wan, X. S., Sheng, H. X., Dai, M., Zhang, Y., Shi, D., Trull, T. W., Zhu, Y., Lomas, M. W., and Kao, S. J.: Ambient nitrate switches the ammonium consumption pathway in the euphotic ocean, Nat. Commun., 9, 1-9, https://doi.org/10.1038/s41467-018-03363-0, 2018.

Ward, B. B.: Light and substrate concentration relationships with marine ammonium assimilation and oxidation rates, Mar. Chem., 16, 301-316, https://doi.org/10.1016/0304-4203(85)90052-0, 1985.

Ward, B. B.: Temporal variability in nitrification rates and related biogeochemical factors in Monterey Bay, Mar. Ecol. Prog. Ser., 292, 97-109, https://doi.org/10.3354/meps29207, 2005.

Ward, B. B.: Measurement and distribution of nitrification rates in the oceans, Method Enzymol., 486, 307-323, https://doi.org/10.1016/B978-0-12-381294-0.00013-4, 2011.

Weber, L. H. and El-Sayed, S. Z.: Contributions of the net, nanoand picoplankton to the phytoplankton standing crop and primary productivity in the Southern Ocean, J. Plankton Res., 9, 973-994, https://doi.org/10.1093/plankt/9.5.973, 1987.

Wei, T. and Simko, V.: R package "corrplot": Visualization of a Correlation Matrix v0.84, https://github.com/taiyun/corrplot, 2017.

Weir, I., Fawcett, S., Smith, S., Walker, D., Bornman, T., and Fietz, S.: Winter biogenic silica and diatom distributions in the Indian sector of the Southern Ocean, Deep-Sea Res. Pt. I, 166, 103421, https://doi.org/10.1016/j.dsr.2020.103421, 2020.

Welschmeyer, N. A.: Fluorometric analysis of chlorophyll a in the presence of chlorophyll $\mathrm{b}$ and pheopigments, Limnol. Oceanogr., 39, 1985-1992, https://doi.org/10.4319/lo.1994.39.8.1985, 1994.

Wickham, H.: ggplot2: Elegant Graphics for Data Analysis, Springer-Verlag New York, ISBN 978-3-319-24277-4, 2016.

Wickham, H. and Seidel, D.: scales: scale functions for visualisation, $\mathrm{R}$ package version 1.1.1, https://CRAN.R-project.org/ package $=$ scales, 2020.

Wood, S.: Generalized Additive Models: An Introduction with R, 2nd edition, Chapman and Hall/CRC, ISBN 9781498728331, 2017.

Xu, G., Chen, L., Zhang, M., Zhang, Y., Wang, J., and Lin, Q.: Year-round records of bulk aerosol composition over the Zhongshan Station, Coastal East Antarctica, Air. Qual. Atmos. Hlth., 12, 271-288, https://doi.org/10.1007/s11869-018-0642-9, 2019.

Yool, A., Martin, A. P., Fernández, C., and Clark, D. R.: The significance of nitrification for oceanic new production, Nature, 447, 999-1002, https://doi.org/10.1038/nature05885, 2007.

Zakem, E. J., Al-Haj, A., Church, M. J., Van Dijken, G. L., Dutkiewicz, S., Foster, S. Q., Fulweiler, R. W., Mills, M. M., and Follows, M. J.: Ecological control of nitrite in the upper ocean, Nat. Commun., 9, 1-13, https://doi.org/10.1038/s41467018-03553-w, 2018. 
Zhou, J., Delille, B., Kaartokallio, H., Kattner, G., Kuosa, H., Tison, J. L., Autio, R., Dieckmann, G. S., Evers, K. U., Jørgensen, L., and Kennedy, H.: Physical and bacterial controls on inorganic nutrients and dissolved organic carbon during a sea ice growth and decay experiment, Mar. Chem., 166, 59-69, https://doi.org/10.1016/j.marchem.2014.09.013, 2014. 